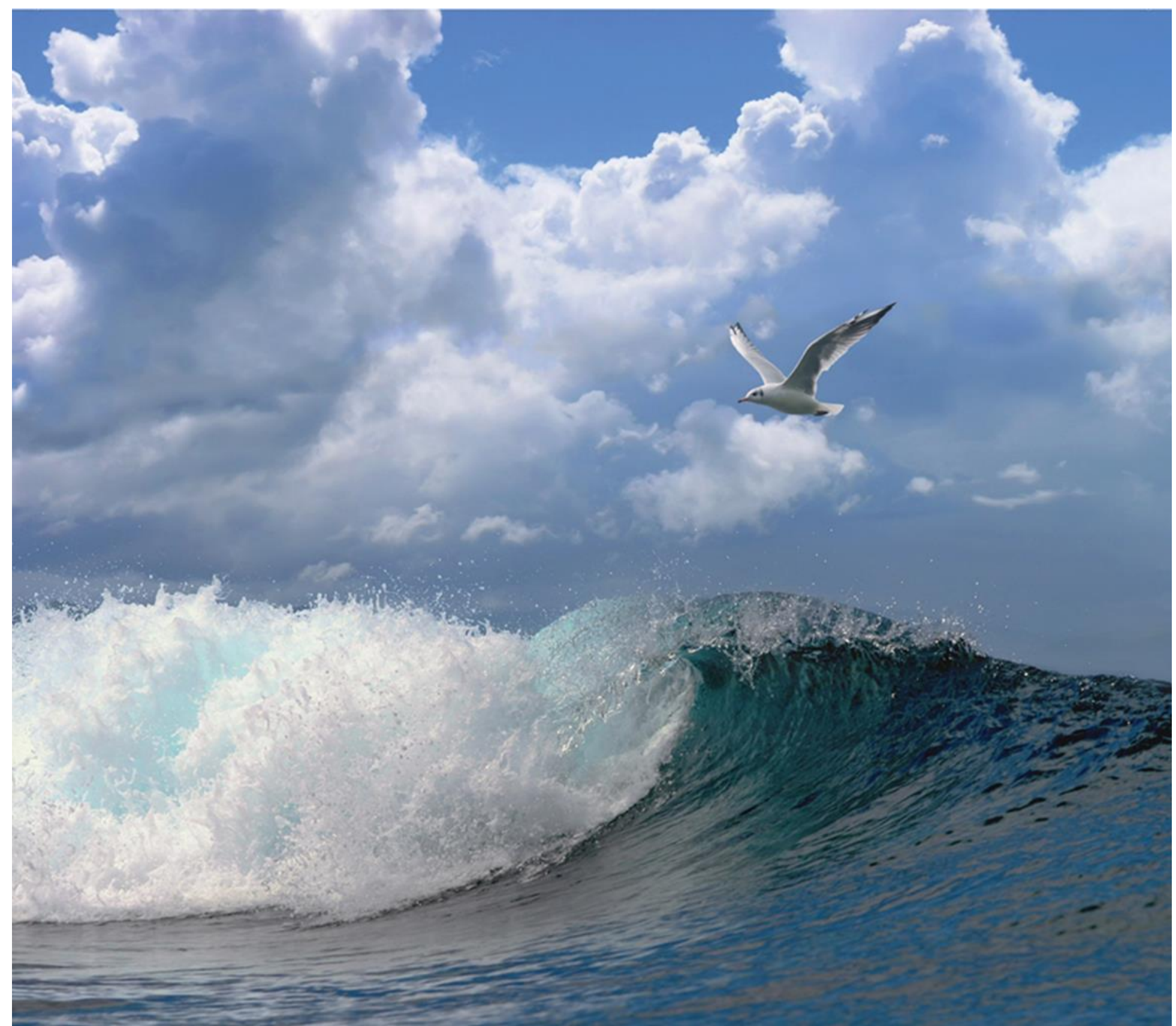

Aanvulling op de passende beoordeling mechanische winning van pieren door Arenicola B.V. op de Vlakte van Kerken (Waddenzee) 


\section{Aanvulling op de passende beoordeling mechanische winning van pieren door Arenicola B.V. op de Vlakte van Kerken (Waddenzee)}

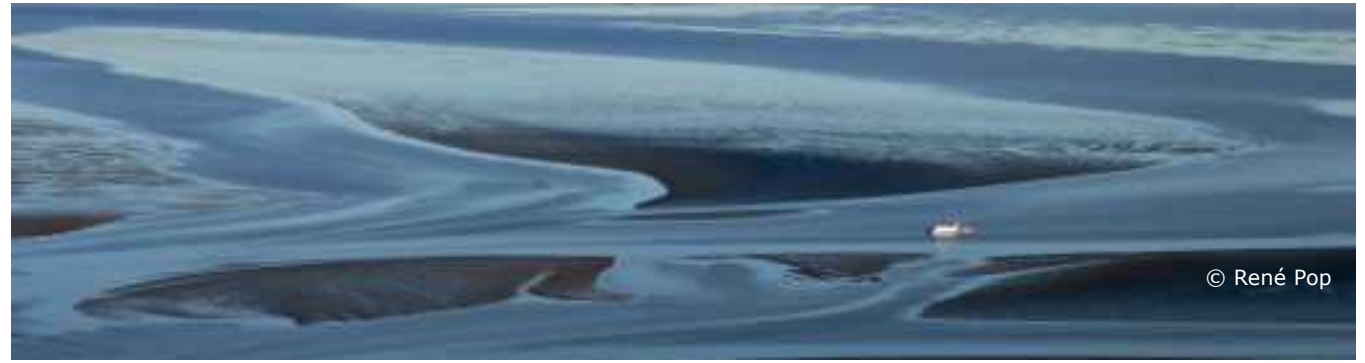


Keywords: wadpieren, Arenicola marina, pierenvisserij, duurzaam

Opdrachtgever: Arenicola B.V.

T.a.v.: Johan Bremer

Langeveldstraat $8 \mathrm{~b}$

1795 AG De Cocksdorp

Dit rapport is gratis te downloaden van https://doi.org/10.18174/508852

Wageningen Marine Research verstrekt geen gedrukte exemplaren van rapporten.

Wageningen Marine Research is ISO 9001:2015 gecertificeerd.

\section{(C) Wageningen Marine Research}

Wageningen Marine Research, instituut binnen de rechtspersoon Stichting Wageningen Research, hierbij vertegenwoordigd door Dr. M.C.Th. Scholten, Algemeen directeur

KvK nr. 09098104,

WMR BTW nr. NL 8113.83.696.B16.

Code BIC/SWIFT address: RABONL2U

IBAN code: NL 73 RABO 0373599285
Wageningen Marine Research aanvaardt geen aansprakelijkheid voor gevolgschade, noch voor schade welke voortvloeit uit toepassingen van de resultaten van werkzaamheden of andere gegevens verkregen van Wageningen Marine Research. Opdrachtgever vrijwaart Wageningen Marine Research van aanspraken van derden in verband met deze toepassing.

Alle rechten voorbehouden. Niets uit deze uitgave mag weergegeven en/of gepubliceerd worden, gefotokopieerd of op enige andere manier gebruikt worden zonder schriftelijke toestemming van de uitgever of auteur. 


\section{Inhoud}

$1 \quad$ Inleiding $\quad 4$

2 Beleid $\quad 6$

$3 \quad$ De activiteit mechanische winning van pieren $\quad 7$

$\begin{array}{lll}3.1 & \text { Werkwijze } & 7\end{array}$

$\begin{array}{ll}3.2 & \text { Locatie van de activiteit }\end{array}$

$\begin{array}{ll}3.3 & \text { Omvang van de activiteit }\end{array}$

4 Beschermde natuurwaarden en kenmerken $\quad 10$

4.1 Beschermde natuurwaarden en kenmerken $\quad 10$

$\begin{array}{ll}\text { 4.1.1 Natura 2000-gebied Waddenzee } & 10\end{array}$

4.1.2 Natura 2000-gebied Duinen en Lage Land van Texel 13

$\begin{array}{lll}4.2 & \text { Relevante beschermde natuurwarden en kenmerken } & 14\end{array}$

$\begin{array}{llr}5 & \text { Effectenanalyse } & 16\end{array}$

$\begin{array}{llr}5.1 & \text { Habitattypen } & 16\end{array}$

$\begin{array}{lll}5.1 .1 & \text { Monitoring van bodemfauna } & 16\end{array}$

$\begin{array}{lll}5.1 .2 & \text { Effecten als gevolg van stikstofdepositie } & 18\end{array}$

$\begin{array}{lll}5.1 .3 \text { Conclusie } & 18\end{array}$

\begin{tabular}{ll}
5.2 & Habitat(richtlijn)soorten \\
\hline
\end{tabular}

$\begin{array}{lll}5.3 & \text { Vogels } & 20\end{array}$

5.3.1 Aantal relevante vogelsoorten in en nabij de Vlakte van Kerken 20

$\begin{array}{lll}5.3 .2 & \text { Verstoring } & 24\end{array}$

$\begin{array}{ll}\text { 5.3.3 Voedselbeschikbaarheid } & 24\end{array}$

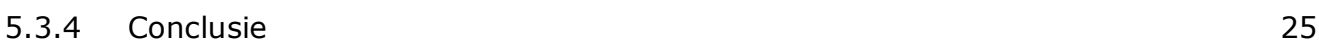

5.4 Belangrijke afwegingen in verband met het Beschermd Staatsreservaat Waddenzee en het Beschermd natuurmonument Schorren van de Eendracht 26

$\begin{array}{llr}6 & \text { Mitigatie } & 27\end{array}$

$7 \quad$ Cumulatie $\quad 28$

$\begin{array}{lll}7.1 & \text { Cumulatie door meerdere pierenwinlocaties } & 28\end{array}$

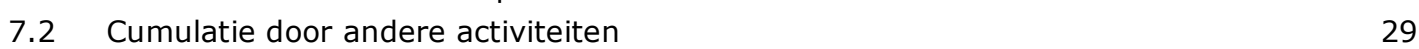

$8 \quad$ Alternatieven voor mechanische pierenwinning $\quad 31$

$9 \quad$ Conclusies en aanbevelingen $\quad 32$

$\begin{array}{lll}10 & \text { Kwaliteitsborging } & 33\end{array}$

$\begin{array}{lr}\text { Literatuur } & 34\end{array}$

$\begin{array}{ll}\text { Verantwoording } & 36\end{array}$

$\begin{array}{lll}\text { Bijlage } 1 & \text { Lijst met werkwijze Arenicola B.V. } & 37\end{array}$

$\begin{array}{lll}\text { Bijlage } 2 & \text { Broedvogels van De Schorren } & 39\end{array}$

Bijlage $3 \quad$ Broedvogels van De Volharding 442 


\section{$1 \quad$ Inleiding}

Gedeputeerde Staten van Noord-Holland hebben op 30 juni 2010 aan Arenicola B.V. een vergunning verleend conform artikel 19d, lid 1 van de Natuurbeschermingswet (Nb-wet) voor het mechanisch winnen van wadpieren binnen het concessiegebied "Vlakte van Kerken". Deze vergunning was geldig tot en met de eerste beheerplanperiode voor het Natura 2000-gebied Waddenzee, doch uiterlijk tot 1 januari 2019. De beheerplanperiode voor het Natura 2000-gebied Waddenzee loopt tot 2022. Op 20 december 2018 hebben Gedeputeerde Staten van Noord-Holland aan Arenicola B.V. een vergunning verleend conform artikel 2.7, tweede lid Wet Natuurbescherming (Wnb) betreffende het ongewijzigd voortzetten van de bij Natuurbeschermingswetvergunning van 30 juni 2010 vergunde activiteiten. De beschrijving van het project in de aanvraag en de bijlagen bij deze vergunning maken onderdeel uit van deze vergunning. De vergunning is geldig tot en met 31 december 2028.

Voor de aanvraag van een volgende vergunning kan eventueel een aanvulling nodig zijn op de Passende Beoordeling (PB) van Fey-Hofstede \& Smit (2009), in het vervolg aangeduid als de PB-2009, die ten grondslag lag aan de Nb-wetvergunning die op 2010 werd verstrekt (Gedeputeerde Staten Provincie Noord-Holland, 2010a). Arenicola B.V. heeft in augustus 2018 aan WMR gevraagd deze aanvulling op te stellen ten behoeve van eventueel toekomstig beleid.

\section{Nb-wetvergunning 2010-2019}

In de Nb-wetvergunning van $2010 \mathrm{t} / \mathrm{m} 2018$ staat de verplichting een monitoringonderzoek op te starten en uit te (laten) voeren. Deze verplichting is als volgt geformuleerd: Het monitoringonderzoek moet kunnen aantonen welke ontwikkeling er in de bodemfauna optreedt na beroering van de wadbodem als gevolg van mechanische winning van wadpieren. Een studie van reeds beschikbare en lopende onderzoeks- en monitoringprogramma's kan worden uitgevoerd voorafgaand aan het opzetten van een monitoringonderzoek. De monitoring is erop gericht om duidelijkheid te verkrijgen omtrent de resterende onzekerheden over hersteltijden van het habitattype H1140A binnen een pierenwingebied. Het gaat niet om inzicht in de gehele Waddenzee, maar om inzicht te verkrijgen in de ontwikkeling van de vergunde pierenwinlocatie. Als uit meetresultaten blijkt dat de kwaliteit van het habitattype H1140A minder dan vijf jaar nodig heeft om te herstellen zou er zelfs aanleiding kunnen zijn om deze kortere hersteltijd in de toekomst in de vergunningvoorschriften te verwerken. Aan deze monitoringsverplichting is inmiddels voldaan. Dit wordt in de volgende paragraaf beschreven.

\section{Monitoringsonderzoek}

Het NIOZ voert sinds 2008 jaarlijks een monitoringsprogramma voor macrozoöbenthos uit op ca. 4500 stations verdeeld over de gehele Nederlandse Waddenzee. Monsterstations liggen verdeeld over een raster met vaste afstanden tussen stations van 500 meter. Naast deze stations is er een aantal extra stations dat op de lijnen tussen de gridpunten ligt. Dit monitoringsprogramma heet SIBES (Synoptic Intertidal Benthic Survey) en voor details over het programma, bemonsterings- en analysemethoden wordt verwezen naar Compton et al. (2012 \& 2013). Voor het, vanuit de Nbwetvergunning, verplichte monitoringonderzoek naar effecten op de bodemfauna door wadpierenvisserij op de Vlakte van Kerken is gebruik gemaakt van de gegevens uit de database van het SIBES. In opdracht van Arenicola B.V. heeft het NIOZ een analyse gedaan van de monitoringsgegevens in de periode 2008-2011 (Drent, 2013) en 2012 -2014 (Drent, 2015) gericht op beantwoording van de vraag of de bodemfauna in het gebied waar naar wadpieren is gevist anders is of zich anders ontwikkelt dan in een onbevist referentiegebied met vergelijkbare omgevingskenmerken als het beviste gebied.

\section{PB-2009}

De Passende Beoordeling uit 2009 (Fey-Hofstede \& Smit 2009) beschrijft de passende beoordeling voor de vergunningaanvraag van VOF Zeeaashandel Arenicola betreffende het mechanisch winnen van pieren in de concessiegebieden op de Vlakte van Kerken bij Texel. De vergunningaanvraag uit 2009 betrof net als nu twee wingebieden nabij Texel op de Vlakte van Kerken. De totale oppervlakte van deze wingebieden bedroeg toen ongeveer 1737 ha $(0,7 \%$ van de oppervlakte van de Nederlandse Waddenzee), en met aftrek van geulen een werkbaar gebied van 1500 ha. De wingebieden waren in deze hoedanigheid al sinds 1976 in gebruik. In de PB-2009 worden mogelijke effecten op Habitattype 
1140 en 1110 en de relevante vogelrichtlijnsoorten en habitatrichtlijnsoorten onderzocht. Relevante mogelijke effecten van mechanische pierenwinning betreffen effecten op de bodemgesteldheid (habitattype 1140), voedselbeschikbaarheid voor vogels en verstoring van vogels. Gezien de lokale en beperkte omvang van de aangevraagde winning werd geen significante aantasting van het habitattype 1140 , relevante habitatrichtlijnsoorten of vogelrichtlijnsoorten als wezenlijk kenmerk van het beschermde gebied verwacht. In de PB-2009 is geconcludeerd dat het tevens onwaarschijnlijk is dat de aangevraagde activiteiten de eventuele effecten van andere projecten of activiteiten, zoals garnalen- en handkokkelvisserij, op de relevante natuurwaarden zou versterken. Geconcludeerd is dat de effecten van de aangevraagde activiteit op de Vlakte van Kerken niet significant waren in het licht van de instandhoudingsdoelstellingen zoals beschreven in het profielendocument.

\section{Aanvulling PB-2009}

De aanvulling op de PB-2009 (dit rapport) richt zich op nieuwe informatie t.o.v. 2009. Er is een analyse gemaakt van voor de effectenanalyse relevante aspecten. Dat zijn concreet: veranderingen in de werkwijze van de mechanische pierenwinning door Arenicola B.V., ontwikkelingen in de dichtheid en samenstelling van de bodemfauna in het winningsgebied en de ontwikkelingen van aantallen van potentieel gevoelige broedvogelsoorten in en nabij het winningsgebied en veranderingen van de instandhoudingsdoelstellingen van habitattype, habitatsoorten en vogelsoorten waaraan getoetst moet worden.

Voor dit rapport zijn de volgende activiteiten uitgevoerd: verzamelen van de relevante documenten, actualiseren van gegevens uit Natura 2000-gebied Waddenzee, beoordeling van de effecten van de activiteit mechanische pierenwinning (effectbeoordeling), en het schrijven van een beknopte rapportage.

Er wordt dus niet een nieuwe volledige PB uitgevoerd, maar wel wordt de structuur van een PB gevolgd. De PB van 2009 blijft de basis en hiernaar wordt dus vaak verwezen. Alleen de bovengenoemde aanvullingen (type veranderingen) en de consequenties daarvan worden wel betrokken in de beoordeling en het resultaat daarvan wordt hier gepresenteerd. 


\section{$2 \quad$ Beleid}

Onder Natura 2000-gebieden vallen de gebieden die op grond van de Vogelrichtlijn (Richtlijn 79/409/EEG van de Raad van de Europese Gemeenschappen van 2 april 1979 inzake het behoud van de vogelstand) en Habitatrichtlijn (Richtlijn 92/43/EEG van de Raad van de Europese

Gemeenschappen van 21 mei 1992 inzake de instandhouding van de natuurlijke habitats en de wilde flora en fauna) zijn aangemeld of aangewezen. Voor al deze gebieden gelden instandhoudingsdoelen (IHDs). De essentie van het beschermingsregime voor deze gebieden is dat deze instandhoudingsdoelen niet in gevaar mogen worden gebracht. Om dit toetsbaar te maken kent de Natuurbeschermingswet 1998 (hierna: Nb-wet) voor projecten en andere handelingen die gevolgen voor soorten en habitats van de betreffende gebieden zouden kunnen hebben, een vergunningplicht. De Nb-wet is sinds 1 januari 2017 samen met o.a. de Flora- en faunawet vervangen door de Wet natuurbescherming (Wnb). Gebruik dat is opgenomen in het beheerplan en in overeenstemming met de daarin opgenomen voorwaarden wordt verricht, is vrijgesteld van de vergunningplicht. In 2016 is het Natura 2000 Beheerplan Waddenzee 2016-2022 vastgesteld door de provincies Groningen, Friesland en Noord-Holland en het Ministerie van Economische Zaken. In dat Beheerplan is vastgelegd welke activiteiten zonder vergunning in het kader van de Wet natuurbescherming kunnen worden voortgezet en welke activiteiten vergunningplichtig zijn (of blijven). De mechanische pierenwinning in de Waddenzee blijft vooralsnog vergunningplichtig. Voor het verlenen van een Wnb-vergunning dient voor de voorgenomen activiteit middels een Passende Beoordeling te worden aangetoond dat deze activiteit de natuurlijke kenmerken van het betrokken gebied niet aantast. Het betreft hier een verlenging van een bestaande vergunning waarbij geen wijzigingen in de activiteit plaatsvinden.

Voorwaarde voor een te verlenen vergunning is; het verschaffen van zekerheid, dat de beoogde activiteit geen blijvend significant negatieve effecten op de instandhoudingsdoelstellingen kan veroorzaken. Bij de Passende Beoordeling (PB) wordt de betreffende activiteit, in combinatie met mitigatie en cumulatie, beoordeeld aan de hand van de instandhoudingsdoelstellingen. 


\section{De activiteit mechanische winning van pieren}

\section{$3.1 \quad$ Werkwijze}

De werkwijze van Arenicola B.V. is beschreven in Bijlage 1. De werkwijze volgt de voorschriften in de Nb-wetvergunning van 2010 (Gedeputeerde Staten Provincie Noord-Holland, 2010) en is sindsdien onveranderd. In de vergunningaanvraag voor de periode vanaf 1 januari 2019 is aangegeven dat de maximale diepte van de graver verminderd is naar $35 \mathrm{~cm}$. Bij voorschrift 14 van de vigerende vergunning is de maximale diepte van $40 \mathrm{~cm}$ gewijzigd in $35 \mathrm{~cm}$. Dat wil niet zeggen dat er in voorgaande jaren steeds op die diepte is gevist.

\subsection{Locatie van de activiteit}

De locatie van de activiteit is niet veranderd. De grenzen van het concessiegebied Vlakte van Kerken zijn hetzelfde gebleven als vermeld in de PB van 2009 (Fey-Hofstede \& Smit, 2009) en de Nbwetvergunning van 2010 (Gedeputeerde Staten Provincie Noord-Holland, 2010a).

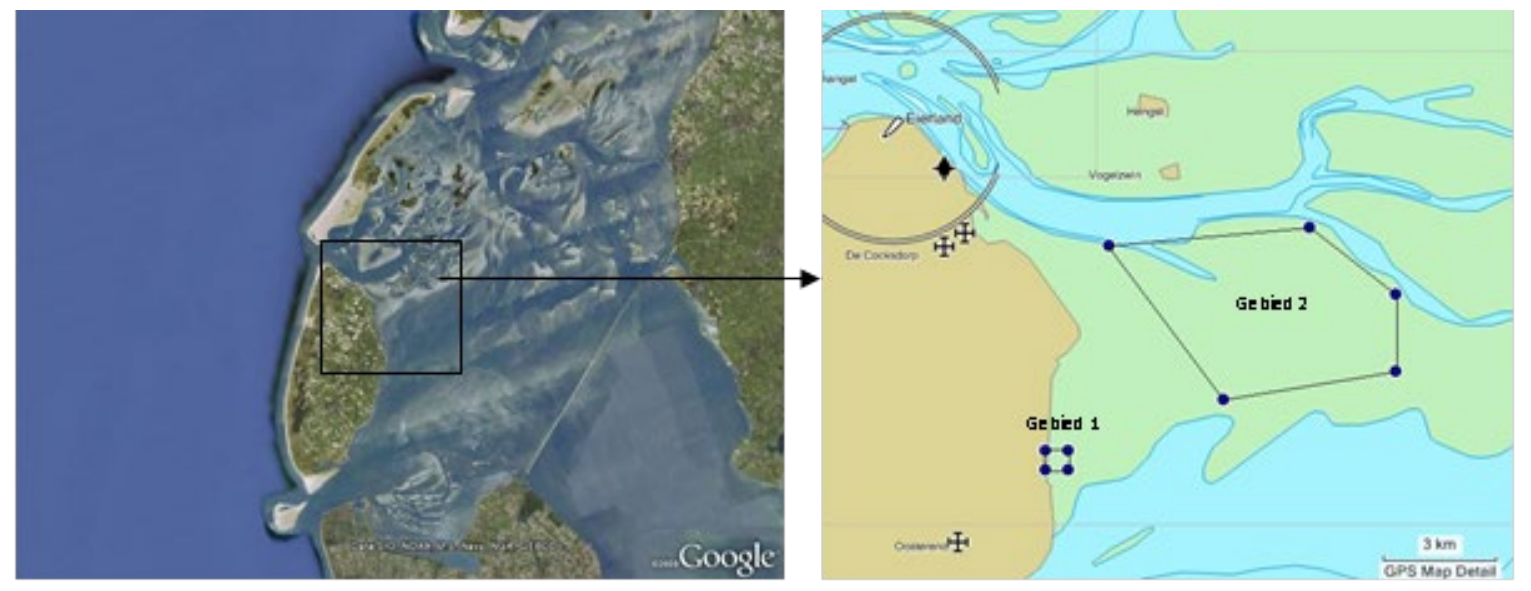

Figuur 1. Luchtfoto van het westelijk deel van de Waddenzee met een uitsnede (zeekaart) van de Vlakte van Kerken met daarin de pierenwingebieden (Fey-Hofstede \& Smit, 2009)

\subsection{Omvang van de activiteit}

Het mechanisch winnen van wadpieren op de Vlakte van Kerken bij Texel betreft een relatief kleinschalige activiteit. De wingebieden op de Vlakte van Kerken beslaan samen ruim 1737 ha. Dat is $0,7 \%$ van de oppervlakte van de Nederlandse Waddenzee (257.266 ha). Het aanwezige HR habitattype in het gebied is $\mathrm{H} 1140$.

In de Nb-wetvergunning (GD PNH, 2010) werd uitgegaan van een maximaal bevist oppervlakte per jaar van 75 ha. Deze oppervlakte is gerelateerd aan het benodigde werkoppervlak van het bedrijf dat pieren wint op het Balgzand. Dat betekent dat er door Arenicola B.V. jaarlijks 0,083\% van de oppervlakte van habitattype H1140 (90.725 ha) in de Waddenzee mag worden bevist. 
De jaarlijks beviste oppervlakte van de wadbodem is variabel. Dit is afhankelijk van het aantal aanwezige pieren per $\mathrm{m}^{2}$ en het aantal opgeviste wadpieren. Leopold \& Bos (2009) rekenden met een dichtheid van 20 pieren per $\mathrm{m}^{2}$ en kwamen voor een gemiddelde jaarlijkse oogst aan wadpieren van 5,4 miljoen pieren uit op een beviste oppervlakte van 27 ha en dat is $0,03 \%$ van $\mathrm{H} 1140$ in de Waddenzee. De huidige pierendichtheid in het deel van het concessiegebied waar gevist wordt, is nu volgens Arenicola B.V. hoger, namelijk ca. 30 pieren per $\mathrm{m}^{2}$. Dat zou betekenen dat voor een oogst van 5,4 miljoen pieren een oppervlakte van 18 ha is bevist. Dit is $0,02 \%$ van $\mathrm{H} 1140$ in de Waddenzee. Uit monitoringgegevens van het gebied voor de periode 2012 t/m 2014 (Drent, 2015) blijkt dat de dichtheid aan pieren zich dichterbij de 20 pieren per $\mathrm{m}^{2}$ bevindt. De berekening van Leopold $\&$ Bos (2009) kan daarom worden aangehouden. Een bevist oppervlakte van 27 ha is $1.6 \%$ van het concessiegebied van 1737 ha. Echter, niet het hele concessiegebied is bevisbaar voor Arenicola. Het bevisbare deel is 1500 hectare groot (Tabel 1). Het jaarlijks beviste areaal van 27 hectare is hiervan $1.8 \%$ wat inhoudt dat, indien vissporen in verschillende jaren nooit zouden overlappen, het 56 jaar zou duren voordat het hele bevisbare deel van het concessiegebied éénmaal is bevist.

Tabel 1. Beschrijving van het ruimtegebruik van de activiteit door Arenicola B.V. in de periode 2010-2019.

\begin{tabular}{|l|c|}
\hline Gebied & $\begin{array}{c}\text { Oppervlakte } \\
\text { (ha) }\end{array}$ \\
\hline Concessiegebied, totale oppervlakte & 1737 \\
\hline Concessiegebied, bevisbare deel & 1500 \\
\hline Vergunde bevisbare oppervlakte (ha) per jaar & 75 \\
\hline Daadwerkelijk beviste oppervlakte (ha) per jaar & 27 \\
\hline
\end{tabular}

Arenicola B.V. is al decennialang actief met de mechanische pierenwinning op de Vlakte van Kerken en streeft er in haar bedrijfsvoering uiteraard naar om de visserij zo efficiënt mogelijk uit te voeren. Arenicola B.V. stuurt jaarlijks een overzicht van de gemaakte vistreksporen aan de Regionale Uitvoeringsdienst (RUD) Noord-Holland Noord. Een vistrekspoor is maximaal 500 meter lang en 1,20 meter breed. Per etmaal worden maximaal 5 treksporen getrokken. Uit de geregistreerde gegevens kan de RUD het voor de pierenwinning beroerde oppervlak aan wadbodem berekenen. Een andere maat voor de omvang van de activiteit is het aantal pieren per liter brandstof als maat voor de CPUE (catch per unit effort). Er zijn cijfers beschikbaar voor de jaarlijkse opbrengst van wadpieren per liter brandstof in de afgelopen periode van 29 jaar. In Figuur 2 is de opbrengst aan wadpieren per liter brandstof weergegeven. Er is een significante, stijgende trend zichtbaar $\left(R^{2}=0.5078 ; n=29 ; P<0.001\right)$. De visserij is dus steeds efficiënter geworden, omdat de dichtheid aan (verhandelbare) pieren is toegenomen maar ook de mogelijkheden voor gebiedsgebruik met behulp van eigen steunzender zijn geoptimaliseerd. 


\section{Arenicola $\quad \mathrm{y}=4.8365 \mathrm{x}-9327.3$ $\mathrm{R}^{2}=0.5078$}

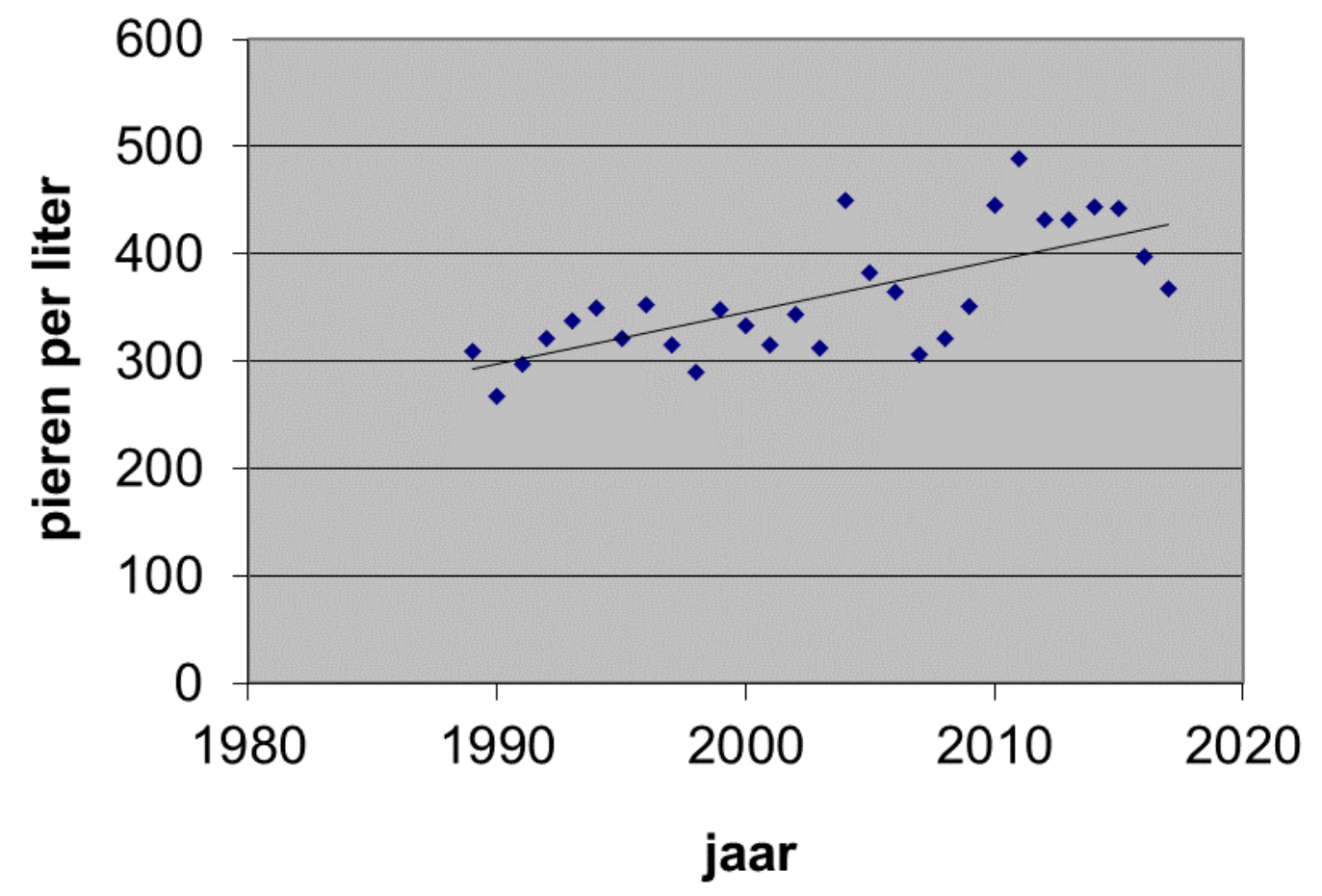

Figuur 2. De jaarlijkse visserij efficiëntie van Arenicola, uitgedrukt in aantallen geoogste wadpieren per liter gebruikte brandstof (catch per unit effort, CPUE) op Vlakte van Kerken (data 1989 t/m 2017). Data Arenicola B.V.. 


\section{$4 \quad$ Beschermde natuurwaarden en kenmerken}

\subsection{Beschermde natuurwaarden en kenmerken}

In de PB-2009 is de toetsing gericht op de instandhoudingsdoelstellingen (IHDs) van twee Natura 2000-gebieden, namelijk Waddenzee en Duinen en Lage Land Texel. In de Nb-wetvergunning van 2010 (Gedeputeerde Staten Provincie Noord-Holland, 2010a) is de toetsing alleen gericht op de natuurwaarden in het Natura 2000-gebied Waddenzee zoals beschreven in het aanwijzingsbesluit (Ministerie van LNV, 2009a). In het onderhavige rapport behandelen we de beide Natura 2000gebieden evenals de wijzigingen in de instandhoudingsdoelstellingen ten opzichte van 2009.

\subsubsection{Natura 2000-gebied Waddenzee}

Bij de beoordeling van de aangevraagde activiteiten en de mogelijke negatieve effecten hiervan, wordt uitgegaan van de natuurwaarden in het Natura 2000-gebied Waddenzee, zoals die zijn beschreven in het Aanwijzingsbesluit Waddenzee uit februari 2009 (Ministerie van LNV, 2009a). In Tabel 2 staan de kwalificerende habitats en soorten. Daarin is aangegeven of er voor het oppervlakte en de kwaliteit een behoudsdoelstelling geldt $(=)$ of een herstelopgave $(+)$.

In de PB-2009 was de bonte strandloper als broedvogel van het Habitatrichtlijngebied Waddenzee opgenomen. Deze soort is echter in het Aanwijzingsbesluit Waddenzee komen te vervallen als kwalificerende broedvogel met een Instandhoudingsdoel (IHDs). Dit is bevestigd in de brief voor gedeputeerde Staten (Fey-Hofstede \& Smit, 2009). 
Tabel 2. Instandhoudingsdoelstellingen en kernopgaven van Natura 2000-gebied Waddenzee. Aanwijzingsbes/uit februari 2009 (Ministerie van LNV, 2009a).

\begin{tabular}{|c|c|c|c|c|c|}
\hline Instandhoudingsdoelstelling & 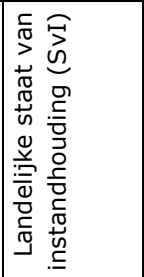 & 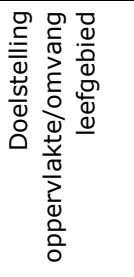 & 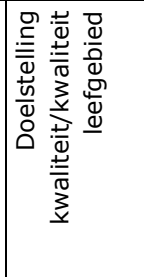 & 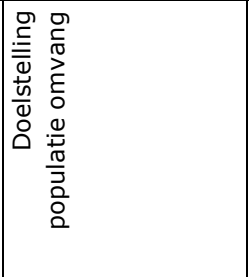 & 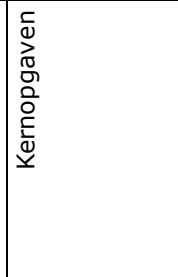 \\
\hline $\begin{array}{l}\text { H1110A - Permanent overstroomde zandbanken } \\
\text { (getijdengebied) }\end{array}$ & - & $=$ & $>$ & & $1.03, \mathrm{~W}$ \\
\hline H1130 - Estuaria & -- & $=$ & $>$ & & \\
\hline H1140A - Slik- en zandplaten (getijdengebied) & - & $=$ & $>$ & & $1.10, \mathrm{~W}$ \\
\hline H1320 - Slijkgrasvelden & -- & $=$ & $=$ & & \\
\hline H1330A - Schorren en zilte graslanden (buitendijks) & - & $=$ & $>$ & & $1.16, \mathrm{~W}$ \\
\hline H1330B - Schorren en zilte graslanden (binnendijks) & - & $=$ & $=$ & & \\
\hline H2110 - Embryonale duinen & + & $=$ & $=$ & & 1.13 \\
\hline H2120 - Witte duinen & - & $=$ & $=$ & & \\
\hline H2130A - *Grijze duinen (kalkrijk) & -- & $=$ & $=$ & & \\
\hline H2130B - *Grijze duinen (kalkarm) & -- & $=$ & $>$ & & \\
\hline H2160 - Duindoornstruwelen & + & $=$ & $=$ & & \\
\hline H1099 - Rivierprik & - & $=$ & $=$ & $>$ & $1.07, \mathrm{~W}$ \\
\hline H1103 - Fint & -- & $=$ & $=$ & $>$ & $1.09, \mathrm{~W}$ \\
\hline H1340 - *Noordse woelmuis & -- & $=$ & $=$ & $=$ & \\
\hline H1351 - Bruinvis & - & $=$ & $=$ & $=$ & \\
\hline H1364 - Grijze zeehond & - & $=$ & $=$ & $=$ & $1.11 ; 1.13$ \\
\hline H1365 - Gewone zeehond & - & $=$ & $=$ & $>$ & 1.11 \\
\hline H1903 - Groenknolorchis & -- & $=$ & $=$ & $=$ & \\
\hline \multicolumn{6}{|l|}{ Broedvogelsoorten } \\
\hline A034 - Lepelaar & + & $=$ & $=$ & 430 & \\
\hline A063 - Eider & -- & $=$ & $>$ & 5000 & $1.03, \mathrm{~W}$ \\
\hline A081 - Bruine kiekendief & + & $=$ & $=$ & 30 & \\
\hline A082 - Blauwe kiekendief & -- & $=$ & $=$ & 3 & \\
\hline A132 - Kluut & - & $=$ & $>$ & 3800 & 1.13 \\
\hline A137 - Bontbekplevier & - & $=$ & $=$ & 60 & 1.13 \\
\hline A138 - Strandplevier & -- & $>$ & $>$ & 50 & 1.13 \\
\hline A183 - Kleine mantelmeeuw & + & $=$ & $=$ & 19000 & \\
\hline
\end{tabular}




\begin{tabular}{|c|c|c|c|c|c|}
\hline Instandhoudingsdoelstelling & 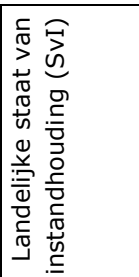 & 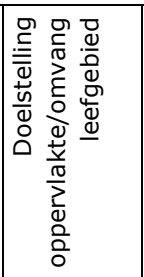 & 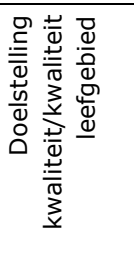 & 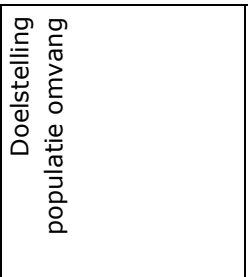 & 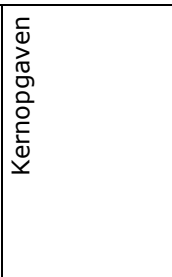 \\
\hline A037 - Kleine zwaan & - & $=$ & $=$ & 1600 & \\
\hline A039 - Toendrarietgans & + & $=$ & $=$ & geen & \\
\hline A043 - Grauwe gans & + & $=$ & $=$ & 7000 & \\
\hline A045 - Brandgans & + & $=$ & $=$ & 36800 & \\
\hline A046 - Rotgans & - & $=$ & $=$ & 26400 & \\
\hline A048 - Bergeend & + & $=$ & $=$ & 38400 & \\
\hline A050 - Smient & + & $=$ & $=$ & 33100 & \\
\hline A051 - Krakeend & + & $=$ & $=$ & 320 & \\
\hline A052 - Wintertaling & - & $=$ & $=$ & 5000 & \\
\hline A053 - Wilde eend & + & $=$ & $=$ & 25400 & \\
\hline A054 - Pijlstaart & - & $=$ & $=$ & 5900 & \\
\hline A056 - Slobeend & + & $=$ & $=$ & 750 & \\
\hline A062 - Toppereend & -- & $=$ & $>$ & 3100 & \\
\hline A063 - Eider & -- & $=$ & $>$ & $90000-115000$ & 1.11 \\
\hline A067 - Brilduiker & + & $=$ & $=$ & 100 & \\
\hline A069 - Middelste zaagbek & + & $=$ & $=$ & 150 & \\
\hline A070 - Grote zaagbek & -- & $=$ & $=$ & 70 & \\
\hline A103 - Slechtvalk & + & $=$ & $=$ & 40 & \\
\hline A130 - Scholekster & -- & $=$ & $>$ & 140000-160000 & 1.11 \\
\hline A132 - Kluut & - & $=$ & $=$ & 6700 & 1.13 \\
\hline A137 - Bontbekplevier & + & $=$ & $=$ & 1800 & 1.13 \\
\hline A140 - Goudplevier & -- & $=$ & $=$ & 19200 & \\
\hline A141 - Zilverplevier & + & $=$ & $=$ & 22300 & \\
\hline A142 - Kievit & - & $=$ & $=$ & 10800 & \\
\hline A143 - Kanoet & - & $=$ & $>$ & 44400 & 1.11 \\
\hline A144 - Drieteenstrandloper & - & $=$ & $=$ & 3700 & \\
\hline A147 - Krombekstrandloper & + & $=$ & $=$ & 2000 & \\
\hline A149 - Bonte strandloper & + & $=$ & $=$ & 206000 & 1.11 \\
\hline A156 - Grutto & -- & $=$ & $=$ & 1100 & \\
\hline A157 - Rosse grutto & + & $=$ & $=$ & 54400 & 1.11 \\
\hline A160 - Wulp & + & $=$ & $=$ & 96200 & \\
\hline A161 - Zwarte ruiter & + & $=$ & $=$ & 1200 & \\
\hline A162 - Tureluur & - & $=$ & $=$ & 16500 & \\
\hline A164 - Groenpootruiter & + & $=$ & $=$ & 1900 & \\
\hline A169 - Steenloper & -- & $=$ & $>$ & $2300-3000$ & 1.11 \\
\hline A197 - Zwarte stern & -- & $=$ & $=$ & 23000 & \\
\hline
\end{tabular}

\section{Legenda}

Habitattype, soorten, broedvogels en niet-broedvogels

Landelijke staat van instandhouding

$+\quad$ gunstig

matig gunstig

zeer ongunstig

Habitattypen

Doelstelling voor oppervlakte en/of kwaliteit 


\subsubsection{Natura 2000-gebied Duinen en Lage Land van Texel}

Er zijn 13 broedvogelsoorten van Natura 2000-gebied "Duinen en Lage Land van Texel" die een instandhoudingsdoelstelling hebben (zie Tabel 3). Een deel van deze broedvogelsoorten foerageert in de nabijgelegen Vlakte van Kerken en kunnen in potentie negatief beïnvloed worden door mechanische pierenwinning. In de PB-2009 wordt daarom aandacht besteed aan de instandhoudingsdoelstellingen (IHDs) in dit geval van de deelgebieden Drijver's vogelweid de Bol en Wagejot: veel aanpassingen in IHDs maar die IHDs zijn niet relevant i.v.m. mechanische pierenwinning. Van 20 habitattypen, een habitatsoort (grijze zeehond) en twee broedvogelsoorten (strandplevier, velduil) zijn instandhoudingsdoelstellingen in het aanwijzingsbesluit anders dan vermeld in de PB van Fey-Hofstede \& Smit (2009).

Tabel 3. Instandhoudingsdoelstellingen en kernopgaven van Natura 2000-gebied Duinen en Lage Land Texel. Aanwijzingsbesluit februari 2009 (Min. LNV, 2009b).

\begin{tabular}{|c|c|c|c|c|c|}
\hline Instandhoudingsdoelstelling & 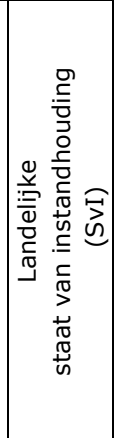 & 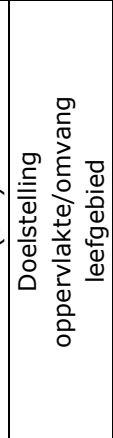 & 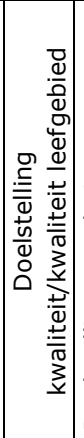 & 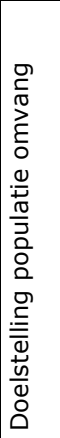 & 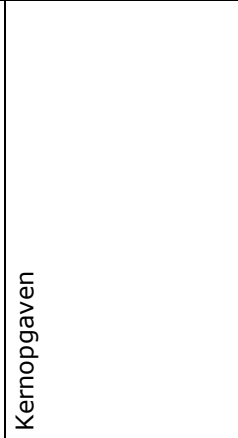 \\
\hline H1140A - Slik- en zandplaten (getijdengebied) & - & $=$ & $=$ & & \\
\hline $1310 \mathrm{~A}$ - Zilte pionierbegroeiingen (zeekraal) & - & $=$ & $=$ & & \\
\hline H1310B - Zilte pionierbegroeiingen (zeevetmuur) & + & $=$ & $=$ & & \\
\hline H1320 - Slijkgrasvelden & -- & $=$ & $=$ & & \\
\hline H1330A - Schorren en zilte graslanden (buitendijks) & - & $=$ & $=$ & & \\
\hline H1330B - Schorren en zilte graslanden (binnendijks) & - & $=$ & $=$ & & \\
\hline H2110 - Embryonale duinen & + & $=$ & $=$ & & \\
\hline H2120 - Witte duinen & - & $=$ & $=$ & & \\
\hline H2130A - *Grijze duinen (kalkrijk) & -- & $>$ & $>$ & & $2.02, \mathrm{SG}$ \\
\hline H2130B - *Grijze duinen (kalkarm) & -- & $>$ & $>$ & & $2.02, \mathrm{SG}$ \\
\hline H2130C - *Grijze duinen (heischraal) & -- & $>$ & $>$ & & $2.02, \mathrm{SG} ; 2.06, \mathrm{~W}$ \\
\hline H2140A - *Duinheiden met kraaihei (vochtig) & - & $=(<)$ & $=$ & & \\
\hline H2140B - *Duinheiden met kraaihei (droog) & - & $=$ & $=$ & & \\
\hline H2150 - *Duinheiden met struikhei & + & $=$ & $=$ & & \\
\hline H2160 - Duindoornstruwelen & + & $=(<)$ & $=$ & & \\
\hline H2170 - Kruipwilgstruwelen & - & $=$ & $=$ & & \\
\hline H2180A - Duinbossen (droog) & + & $=(<)$ & $>$ & & \\
\hline H2180B - Duinbossen (vochtig) & - & $=(<)$ & $>$ & & \\
\hline H2180C - Duinbossen (binnenduinrand) & - & $=$ & $>$ & & $2.08, \mathrm{~W}$ \\
\hline H2190A - Vochtige duinvalleien (open water) & - & $=$ & $>$ & & $2.05, \mathrm{SG}, \mathrm{W}$ \\
\hline H2190B - Vochtige duinvalleien (kalkrijk) & - & $=$ & $>$ & & $2.05, \mathrm{SG}, \mathrm{W}$ \\
\hline
\end{tabular}




\begin{tabular}{|c|c|c|c|c|c|}
\hline Instandhoudingsdoelstelling & 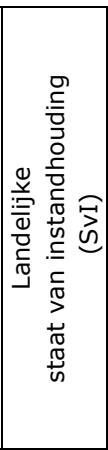 & 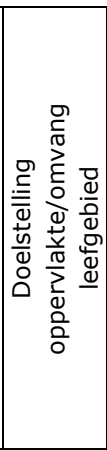 & 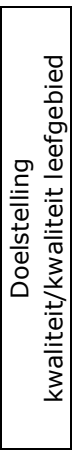 & 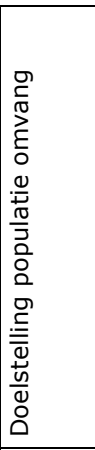 & 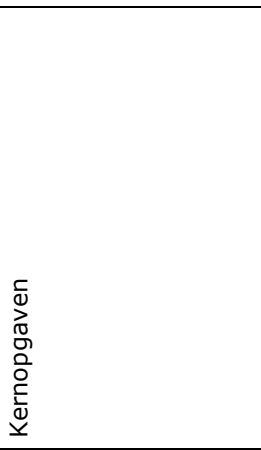 \\
\hline H2190C - Vochtige duinvalleien (ontkalkt) & - & $=$ & $>$ & & $2.05, \mathrm{SG}, \mathrm{W}$ \\
\hline H2190D - Vochtige duinvalleien (hoge moerasplanten) & - & $=$ & $>$ & & $2.05, \mathrm{SG}, \mathrm{W}$ \\
\hline H6230 - *Heischrale graslanden & -- & $=$ & $=$ & & $2.06, \mathrm{~W} ; 2.08, \mathrm{~W}$ \\
\hline \multicolumn{6}{|l|}{$\mathrm{H} 6410$} \\
\hline H6430A - Ruigten en zomen (moerasspirea) & + & $=$ & $=$ & & \\
\hline H6430B - Ruigten en zomen (harig wilgenroosje) & - & $=$ & $=$ & & \\
\hline H6430C - Ruigten en zomen (droge bosranden) & - & $=$ & $=$ & & \\
\hline H7210 - *Galigaanmoerassen & - & $=$ & $=$ & & \\
\hline H1340 - *Noordse woelmuis & -- & $=$ & $>$ & $=$ & $2.05, \mathrm{SG}, \mathrm{W} ; 2.08, \mathrm{~W}$ \\
\hline H1364 - Grijze zeehond & - & $=$ & $=$ & $=$ & \\
\hline H1903 - Groenknolorchis & -- & $=$ & $=$ & $=$ & $2.05, \mathrm{SG}, \mathrm{W}$ \\
\hline A021 - Roerdomp & -- & $=$ & $=$ & 5 & $2.05, \mathrm{SG}, \mathrm{W}$ \\
\hline A034 - Lepelaar & + & $=$ & $=$ & 120 & $2.05, \mathrm{SG}, \mathrm{W}$ \\
\hline A063 - Eider & -- & $=$ & $=$ & 110 & \\
\hline A081 - Bruine kiekendief & + & $=$ & $=$ & 30 & \\
\hline A082 - Blauwe kiekendief & -- & $=$ & $=$ & 20 & $2.02, \mathrm{SG} ; 2.05, \mathrm{SG}, \mathrm{W}$ \\
\hline A132- Kluut & - & $=$ & $=$ & 120 & \\
\hline A137 - Bontbekplevier & - & $>$ & $>$ & 20 & \\
\hline \multicolumn{6}{|l|}{ A138 - Strandplevier } \\
\hline A183 - Kleine mantelmeeuw & + & $=$ & $=$ & 14000 & \\
\hline A195 - Dwergstern & -- & $>$ & $>$ & 40 & \\
\hline A222 - Velduil & -- & $>$ & $>$ & 20 & $2.02, \mathrm{SG} ; 2.05, \mathrm{SG}, \mathrm{W}$ \\
\hline A276 - Roodborsttapuit & + & $=$ & $=$ & 40 & \\
\hline A277 - Tapuit & -- & $>$ & $>$ & 100 & $2.02, \mathrm{SG}$ \\
\hline
\end{tabular}

Legenda

Idem als de legenda bij Tabel 2:

\subsection{Relevante beschermde natuurwaarden en kenmerken}

De lijst van habitattypen en Habitat- en Vogelrichtlijnsoorten die beschermingswaardig zijn in Waddenzee is lang, maar niet ieder genoemd aspect is relevant voor de pierenwinning bij Texel. De habitattypen en Habitat- en Vogelrichtlijnsoorten die relevant zijn in verband met potentiele effecten door de aangevraagde activiteit zijn opgenomen in Tabel 4. Daarbij is ook aangegeven wat op basis van welke type effecten aan potentiele effecten kan worden verwacht en of die effecten potentieel negatief of potentieel positief kunnen zijn. Deze inschatting is overgenomen uit de PB-2009, tenzij anders vermeld. 
Tabel 4. Mogelijke effecten van mechanische pierenwinning op relevante natuurwaarden in de Natura 2000gebieden Waddenzee en Duinen en Lage Land Texel. Afkortingen in de tabel staan voor: + : potentieel positief effect; - : potentieel negatief effect; \pm : zowel potentieel positief als potentieel negatief effect.

\begin{tabular}{|c|c|c|c|c|c|c|c|}
\hline Instandhoudingsdoelstelling & 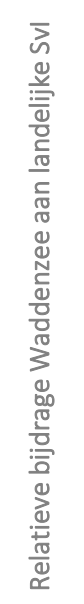 & 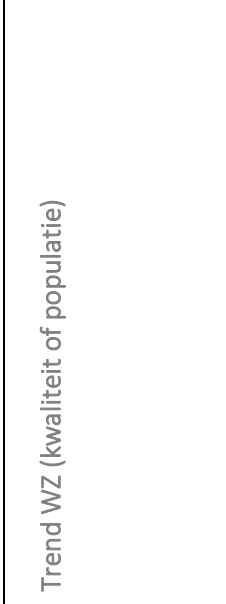 & 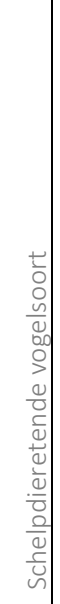 & 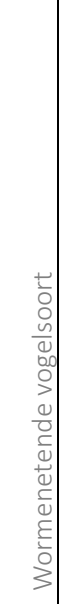 & 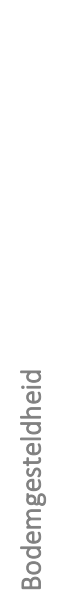 & 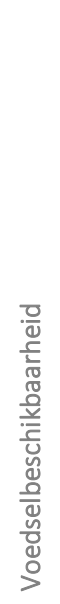 & 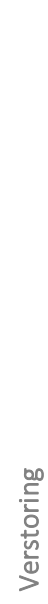 \\
\hline \multicolumn{8}{|l|}{ Habitattypen } \\
\hline $\begin{array}{l}\text { H1110A - Permanent overstroomde zandbanken } \\
\text { (getijdengebied) }\end{array}$ & +++ & Stabiel & & & - & - & \\
\hline H1140A - Slik- en zandplaten (getijdengebied) & +++ & Toenemend & & & - & - & \\
\hline H1364 - Grijze zeehond & & & & & & & - \\
\hline H1365 - Gewone zeehond & & & & & & & - \\
\hline \multicolumn{8}{|l|}{ Broedvogels } \\
\hline A034 - Lepelaar & ++ & Sterke toename & & & & \pm & \\
\hline A063 - Eider & +++ & Onduidelijk & $x$ & & & \pm & \pm \\
\hline \multicolumn{8}{|l|}{ Niet-broedvogels } \\
\hline A034 - Lepelaar & ++ & Sterke toename & & & & \pm & \\
\hline A048 - Bergeend & +++ & Matige toename & $x$ & & & \pm & \\
\hline A063 - Eider & +++ & Onduidelijk & $x$ & & & \pm & \pm \\
\hline A067 - Brilduiker & + & Matige afname & $x$ & & & - & - \\
\hline A130 - Scholekster & +++ & Matige afname & $x$ & & & - & \\
\hline A140 - Goudplevier & +++ & Matige toename & $\mathrm{x}$ & & & - & \\
\hline A141 - Zilverplevier & +++ & Matige toename & & $\mathrm{x}$ & & - & \\
\hline A143 - Kanoet & +++ & Matige toename & $x$ & & & - & \\
\hline A149 - Bonte strandloper & +++ & Matige toename & & & & - & \\
\hline A157 - Rosse grutto & +++ & Matige toename & & $x$ & & - & \\
\hline A160 - Wulp & +++ & Matige toename & $x$ & $x$ & & - & \\
\hline A161 - Zwarte ruiter & +++ & Matige afname & & $\mathrm{x}$ & & \pm & \\
\hline A162 - Tureluur & +++ & Onduidelijk & & $x$ & & - & \\
\hline A164 - Groenpootruiter & +++ & Matige toename & & & & \pm & \\
\hline
\end{tabular}

In Tabel 4 is een kwalificatie van de trend in de Waddenzee toegevoegd. De trend is afkomstig uit het beheerplan voor Natura 2000-gebied Waddenzee (Ministerie van IenM, 2016).

De lepelaar en de eider hebben een instandhoudingsdoelstelling (IHD) als broedvogel in zowel Waddenzee als in Duinen en Lage Land Texel. Deze soorten hebben tevens een IHD als nietbroedvogel in de Waddenzee. Voor Natura 2000-gebied Duinen en Lage Land Texel zijn dit de enige vogelsoorten met een IHD die relevant zijn voor potentiele effecten van de mechanische pierenwinning op de Vlakte van Kerken. Dit is gebaseerd op de PB-2009. 


\section{$5 \quad$ Effectenanalyse}

In dit deel worden de te verwachten effecten van mechanisch pierenwinnen in de aangewezen concessiegebieden op de Vlakte van Kerken behandeld. Het gaat hierbij om mogelijke effecten op habitattypen, Habitatrichtlijnsoorten en Vogelrichtlijnsoorten. Er wordt alleen uitvoerig ingegaan op de consequenties voor de effectbeoordeling van de aspecten die aanvullend zijn ten opzichte van de vorige PB (Fey-Hofstede \& Smit, 2009). De conclusies die worden geformuleerd in paragraaf 5.1.3 zullen een combinatie zijn van de conclusies uit deze PB-2009 en de conclusies uit de aanvullende effectenanalyse.

\subsection{Habitattypen}

$\mathrm{Er}$ is een belangrijke aanvullende bron van informatie over de bodemfauna van de Vlakte van Kerken, namelijk de monitoringsgegevens van SIBES (NIOZ) beschikbaar gekomen en geanalyseerd door Drent (2015). In paragraaf 5.1.1 wordt hierop ingegaan.

Voor de berekening van de effecten van stikstof op de instandhoudingsdoelen is met ingang van 1 juli 2015 de Programmatische Aanpak Stikstof (PAS) in werking getreden. De AERIUS Calculator is als rekeninstrument aangewezen om de hoogte van de stikstofemissie en -depositie te bepalen. Deze berekening is uitgevoerd door Ruimte $\&$ Milieu (2018) en getoetst aan de bestaande norm. In paragraaf 5.1.2. wordt daarop verder ingegaan.

\subsubsection{Monitoring van bodemfauna}

Monitoring van effecten op de bodemfauna door wadpierenvisserij op de Vlakte van Kerken is uitgevoerd in de periode 2008 tot en met 2014 en geanalyseerd voor 2 perioden, namelijk van 2008 t/m 2011 (Drent, 2013) en van 2012 t/m 2014 (Drent, 2015). Een samenvatting van de bevindingen is hieronder weergegeven. Met inachtneming van de beperkingen van het onderzoek waren de conclusies (geciteerd):

- Soortenrijkdom van het beviste gebied is op gebiedsniveau (gammadiversiteit) zeer vergelijkbaar met de gammadiversiteit buiten het concessiegebied. Het referentiegebied heeft een iets lagere gammadiversiteit dan het beviste gebied maar dit verschil is niet statistisch getoetst.

- Soortenrijkdom op het schaalniveau van afzonderlijke stations is niet significant verschillend tussen referentiegebied en bevist gebied.

- De totale dichtheid van alle macrozoöbenthos individuen per vierkante meter (totale dichtheid), gemiddeld over de periode 2012-2014, verschilt niet tussen referentiegebied en bevist gebied.

- De totale biomassa van het macrozoöbenthos $\left(\mathrm{gm}^{-2}\right)$ verschilt niet significant tussen beviste stations en referentiestations.

- De gemiddelde dichtheden van dertien soorten waren over de periode 2008-2011 in drie gevallen significant verschillend tussen referentiegebied en bevist gebied. In alle drie de gevallen was de dichtheid in het beviste gebied hoger dan in het referentiegebied. Geen enkele soort had een significant verschillende dichtheid tussen bevist gebied en de gemiddelde dichtheid buiten het concessiegebied.

- Het voorkomen van soorten (kans om te treffen in een steekmonster) verschilde niet tussen bevist gebied en referentiegebied.

- De temporele ontwikkelingen van gemiddelde soortenrijkdom per station, totale dichtheid en biomassa van het macrozoöbenthos en van de dichtheid van negen afzonderlijk soorten is in de meeste gevallen niet verschillend tussen referentiegebied en bevist gebied. In vijf van de 35 vergelijkingen tussen jaren waren de veranderingen in het referentiegebied anders dan in 
het beviste gebied. Deze verschillen in ontwikkeling tussen jaren resulteerden niet in significante verschillen van deze soorten tussen gebieden.

- De soortensamenstelling in het beviste gebied verschilt niet significant van de soortensamenstelling in het referentiegebied.

- De massaverdelingen van de wadpier, en de lengteverdeling van het nonnetje en de kokkel vertonen een grote overeenkomstigheid tussen bevist gebied en referentiegebied.

- Dit monitoringsonderzoek heeft binnen de beperkingen ervan in het concessiegebied voor de wadpierenvisserij op de Vlakte van Kerken geen overtuigende aanwijzingen gevonden dat de toestand en de ontwikkeling van het macrozoöbenthos in het beviste gebied negatief beïnvloed is door de visserijactiviteiten.

Drent (2015) concludeert verder dat er een aantal significante verschillen gevonden zijn in de vergelijkingen tussen het gebied waar in de periode 2012-2014 naar wadpieren is gevist en het referentiegebied. De vraag is in hoeverre deze verschillen toe te schrijven zijn aan de visserijactiviteit. Wat opvalt is dat de meeste verschillen positief uitvielen voor het beviste gebied, dit waren óf hogere dichtheden óf minder afnames dan in het referentiegebied. Of de hogere dichtheden van opportunistische soorten een respons zijn op visserijactiviteiten is niet vastgesteld. Wel blijkt dat na vergelijking met de overige monsterstations in het Eierlandse Gat gebied vooral het op basis van omgevingsvariabelen gekozen referentiegebied afwijkt binnen het gebied in plaats van de beviste stations.

De eindconclusie van Drent (2015) is dat, als alle gemaakte vergelijkingen in samenhang worden beoordeeld, de toestand en ontwikkeling van de bodemfauna in het beviste gebied niet aantoonbaar negatief is beïnvloed door de visserijactiviteit.

\subsubsection{Strandgaper (Mya arenaria) en hersteltijd}

Volgens de vergunning Gedeputeerde Staten van Noord-Holland, 2010a) moet er naar ten minste drie soorten gekeken worden waaronder in ieder geval de wadpier en de strandgaper (Mya arenaria).

Daarbij moet ook zoveel mogelijk onderscheid gemaakt worden tussen de leeftijdsklassen.

Ut de analyse van Drent (2015) blijkt dat van de typische soorten van habitattype H1140 de wadpier het vaakst in steekmonsters voor kwam, met andere woorden; was het meest algemeen. Andere soorten zoals de zager Alitta virens, de mossel en de strandgaper zijn betrekkelijk zeldzaam in het gebied. De leeftijdsverdeling of lengteverdeling van de strandgaper is niet in de rapportage van Drent (2015) opgenomen, omdat deze soort zowel in de referentie als in het bevist gebied maar zeer beperkt voorkomt. Voor het beoordelen van visserijeffecten in het Eierlandse Gat is de strandgaper geen geschikte soort omdat deze hier in tegenstelling tot op het Balgzand slechts in lage dichtheden voorkomt. De verspreiding van de strandgaper in de Waddenzee lijkt samen te hangen met saliniteit. Bij lage saliniteit vooral onder invloed van spui uit het IJsselmeer zijn strandgapers algemeen, in het relatief zoute Eierlandse Gat, inclusief de Vlakte van Kerken, zijn ze dat niet.

J.J. Beukema beschreef, in een email gericht aan Arenicola B.V., 13 dec. 2011, dat de strandgaper in het Eierlandse Gat, incl. de Vlakte van Kerken, geen geschikte soort is om de hersteltijd van de eventuele effecten van mechanische pierenwinning af te leiden. Door de opzet van het monitoringsprogramma met SIBES en het feit dat de wadpierenvisserij in het Eierlandse Gat een relatief kleinschalige activiteit is op het niveau van het concessiegebied of het kombergingsgebied, kan deze wadpierenvisserij alleen een zichtbaar effect hebben bij zeer lange hersteltijden. Met het monitoringsonderzoek kan dus de vraag niet worden beantwoord of voor het herstel van de kwaliteit van het habitattype H1140A minder dan vijf jaar nodig is. Indien men redeneert dat de strandgaper voor het Eierlandse Gat geen belangrijke soort is, er voor hersteltijd niet speciaal naar aparte soorten behoeft te worden gekeken, maar dat herstel van de biomassa van de fauna ook voldoende is, dan zou de hersteltermijn kunnen worden verkort tot 3 jaar gebaseerd op Beukema et al. (1999) (J.J. Beukema, email gericht aan Arenicola B.V., 13 dec. 2011). Een ander argument daarvoor is dat grote strandgapers geen belangrijke rol lijken te spelen in het functioneren van het Waddenzee ecosysteem. Door hun grote ingraafdiepte zijn ze nauwelijks toegankelijk als prooi voor vogels en ze hebben een relatief trage voedselopname en groei. 
Zelfs indien de pierenvisserij $100 \%$ sterfte zou veroorzaken bij de strandgapers in de beviste sporen binnen het concessiegebied, is de invloed op de stand van de strandgaper in dit gebied

verwaarloosbaar. Dit volgt uit het feit dat jaarlijks slechts $1,6 \%$ van het concessiegebied wordt bevist, waardoor ook de jaarlijkse toegebrachte sterfte $1,6 \%$ van het bestand zal zijn. Met deze visserijsterfte heeft de soort alle tijd zich te herstellen, ook omdat het 56 jaar duurt voordat het hele gebied bevist zal zijn, als visserijsporen nooit overlappen (anders duurt dit nog langer). Deze stelling wordt onderschreven door gegevens verzameld tijdens één dag pierenvissen in februari 2001, dus na twaalf jaren pierenvissen in het concessiegebied. Grote strandgapers kwamen dermate talrijk in het gebied voor, dat het eidereenden loonde om achter het pierenschip op deze bijvangst van het pierenvissen te foerageren (Leopold 2002).

\subsubsection{Effecten als gevolg van stikstofdepositie}

De uitvoering van de voorgenomen activiteit gebeurt met gebruikmaking van een vaartuig. Dit heeft stikstof emissie en -depositie tot gevolg. Ruimte \& Milieu (2018) heeft voor Arenicola B.V. een berekening gemaakt met het programma AERIUS van de depositie van stikstof als gevolg van de bedrijfsactiviteiten. In deze paragraaf wordt de beschrijving en conclusie overgenomen. De motoren van MS Arenicola zijn in 2006 geplaatst en hebben een vermogen van $53 \mathrm{~kW}$. Dit betekent dat deze motoren minimaal aan Euroklasse II voldoen. Per jaar wordt ongeveer 15.000 I diesel verbruikt. Dit resulteert in een NOx-emissie van ongeveer $266,5 \mathrm{~kg} / \mathrm{jaar}$. Deze emissie is naar rato van het oppervlak over de 2 deelgebieden verdeeld. Uit de berekening blijkt dat de depositie op kwetsbare habitattypen en leefgebieden van soorten waarvoor de Natura 2000-gebieden zijn aangewezen kleiner is dan de drempelwaarde van 0,05 mol/ha/jaar. Dit betekent dat de activiteiten van Arenicola B.V. voor wat betreft de uitstoot van stikstof niet vergunningplichtig zijn. Voor de bedrijfsactiviteiten is geen ontwikkelingsruimte benodigd.

\subsubsection{Conclusie}

\section{H1110 Permanent overstroomde zandbanken}

De werkwijze van de mechanische pierenwinning is sinds 2009 niet veranderd. Er zijn geen nieuwe meetgegevens of informatie over de kwaliteit van H1110 in het pierenwingebied beschikbaar gekomen, die kan worden verbonden aan eventuele effecten van de mechanische pierenwinning. De conclusies over de mogelijke effecten op H1110 van het mechanisch winnen van pieren op de Vlakte van Kerken veranderen dus niet ten opzichte van die van de vorige PB (Fey-Hofstede \& Smit, 2009). Onderstaande tabel geeft die conclusies beknopt weer.

\begin{tabular}{|c|c|}
\hline Habitatrichtlijn & $\begin{array}{l}\text { 1110: 'Permanent met zeewater van geringe diepte overstroomde } \\
\text { zandbanken' }\end{array}$ \\
\hline EFFECTEN & Mogelijke effect is lokale vertroebeling van het water. \\
\hline MITIGATIE & Lokale aard en beperkte omvang \\
\hline $\begin{array}{l}\text { MATE VAN VERSTORING } \\
\text { C.Q. VERSLECHTERING }\end{array}$ & $\begin{array}{l}\text { Mechanische pierenwinning op de twee aangewezen locaties op de Vlakte } \\
\text { van Kerken zal naar verwachting niet leiden tot significante aantasting } \\
\text { van het habitattype } 1110 \text { als wezenlijk kenmerk van het beschermde } \\
\text { gebied. }\end{array}$ \\
\hline
\end{tabular}

\section{H1140 Bij eb droogvallende slik- en zandplaten}

De conclusies over de mogelijke effecten op H1140 van het mechanisch winnen van pieren op de Vlakte van Kerken veranderen niet ten opzichte van die van de PB-2009. De ruimtelijke omvang van de mechanische pierenwinning op de Vlakte van Kerken vindt jaarlijks plaats op ongeveer 1500 ha (werkbare deel van $1700 \mathrm{ha}$ ). Dit is $1,7 \%$ van het totale oppervlakte van Habitattype 1140 in de Nederlandse Waddenzee. Wanneer wordt uitgegaan van een maximale hersteltijd van de bodemfauna 
van 5 jaar (naar Beukema, 1995), dan is op enig moment 135 ha (5*27 ha) op de Vlakte van Kerken op enige wijze aangetast. Dit beslaat $0,15 \%$ van het habitattype 1140 in de Nederlandse Waddenzee.

$\mathrm{Er}$ is in de afgelopen vergunningsperiode (2010 t/m 2018) nieuwe informatie beschikbaar betreffende de verspreiding en abundantie van bodemfaunasoorten. Dit betreft het monitoringsonderzoek van Drent (2015) waarvan de eindconclusie is, dat de toestand en ontwikkeling van de bodemfauna in het beviste gebied niet aantoonbaar negatief is beïnvloed door de mechanische pierenvisserijactiviteiten.

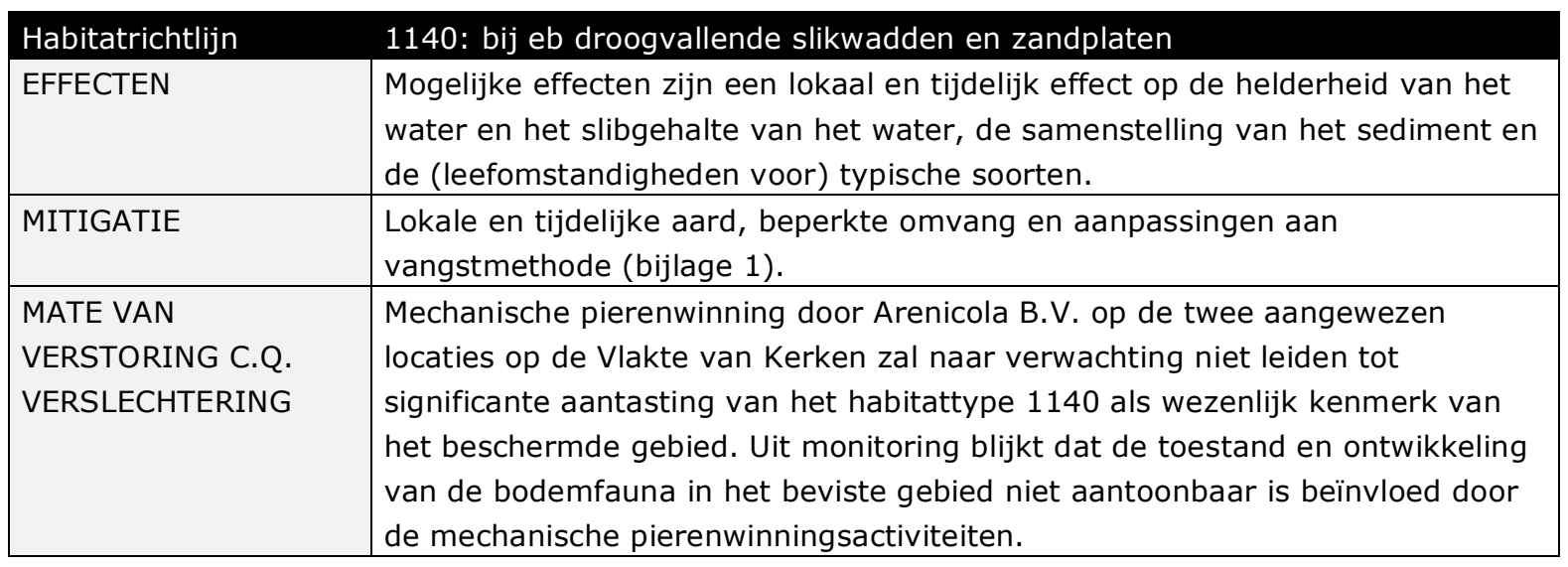

\subsection{Habitat(richtlijn)soorten}

Bij de beoordeling van de aanvraag voor het mechanisch pierenwinnen in de Waddenzee zijn er twee relevante habitatsoorten, namelijk H1364 grijze zeehond en H1365 gewone zeehond.

De werkwijze van de mechanische pierenwinning is sinds 2009 gehandhaafd. Er zijn geen nieuwe meetgegevens of informatie over de grijze zeehond en de gewone zeehond in het pierenwingebied beschikbaar gekomen, die kan worden verbonden aan eventuele effecten de mechanische pierenwinning. De conclusies over de mogelijke effecten op de grijze zeehond en de gewone zeehond van het mechanisch winnen van pieren op de Vlakte van Kerken veranderen dus niet ten opzichte van die van de PB-2009. De stand van zowel de gewone als de grijze zeehond in de Nederlandse Waddenzee is sinds 2009 sterk toegenomen (Brasseur et al. 2017). Onderstaande tabel geeft die conclusies beknopt weer.

\begin{tabular}{|l|l|}
\hline Habitatrichtlijnsoorten & \multicolumn{1}{l|}{ Grijze (H1364) en Gewone zeehond (H1365) } \\
\hline EFFECTEN & Mogelijke effecten zijn verstoringen \\
\hline MITIGATIE & $\begin{array}{l}\text { Het tijdstip van winning (bij hoogwater), de lokale aard en opgelegde } \\
\text { voorwaarde dat rustende en foeragerende zeehonden bij de } \\
\text { pierenwinningactiviteiten niet dichter dan tot op een afstand van } 1.500 \\
\text { m mogen worden genaderd. }\end{array}$ \\
\hline $\begin{array}{l}\text { MATE VAN VERSTORING } \\
\text { C.Q. VERSLECHTERING }\end{array}$ & $\begin{array}{l}\text { Mechanische pierenwinning in de concessiegebieden op de Vlakte van } \\
\text { Kerken door Arenicola B.V. zal naar verwachting niet leiden tot } \\
\text { significante aantasting van relevante habitatrichtlijnsoorten als wezenlijk } \\
\text { kenmerk van het beschermde gebied. }\end{array}$ \\
\hline
\end{tabular}




\subsection{Vogels}

Net als in de PB-2009 kan worden gezegd dat er geen onderzoek bekend is naar de specifieke effecten van mechanische pierenwinning in de huidige vorm op vogels. Relevante mogelijke effecten van mechanische pierenwinning op vogelsoorten betreffen effecten in voedselbeschikbaarheid voor vogels en verstoring.

\subsubsection{Aantal relevante vogelsoorten in en nabij de Vlakte van Kerken}

Er zijn sinds de PB van 2009 telgegevens van vogels van een recentere periode beschikbaar gekomen. Deze worden hier gepresenteerd. Voor het beschrijven van de mogelijke effecten van activiteiten op de Vlakte van Kerken op broedvogels, zijn vooral de vogels die broeden op de Schorren en de Volharding en bovendien een instandhoudingsdoelstelling voor Natura 2000-gebied Waddenzee hebben, van belang. De trends in de aantallen broedparen van deze vogelsoorten zijn weergegeven in bijlagen 2 en 3. De effectenanalyse richt zich van deze broedvogelsoorten vervolgens alleen op de soorten die foerageren op de Vlakte van Kerken en eerder als relevante soorten voor effecten van mechanische pierenwinning zijn beoordeeld (zie paragraaf 4.2). Hierdoor blijven alleen de lepelaar en eider als relevante en potentieel blootgestelde broedvogelsoorten over. Beide soorten broeden op de Schorren, terwijl de eider ook broedt op de Volharding. In Figuur 4 en in Tabel 5 is het aantal gevonden nesten weergegeven. De trend van de lepelaar is stijgend op de Schorren, stijgend tot onduidelijk in de Waddenzee als geheel en ook stijgend over heel Nederland. De trend van de eider is sterk stijgend op de Schorren en onzeker op de Volharding. De trend van de eider in de Waddenzee en landelijk is dalend tot stabiel. Dat betekent dat de lepelaar en de eider het in dit gebied vergelijkbaar tot beter doen dan gemiddeld. Dit geeft dus geen aanwijzing dat de Vlakte van Kerken ongeschikter wordt als foerageergebied voor lepelaar en eider.

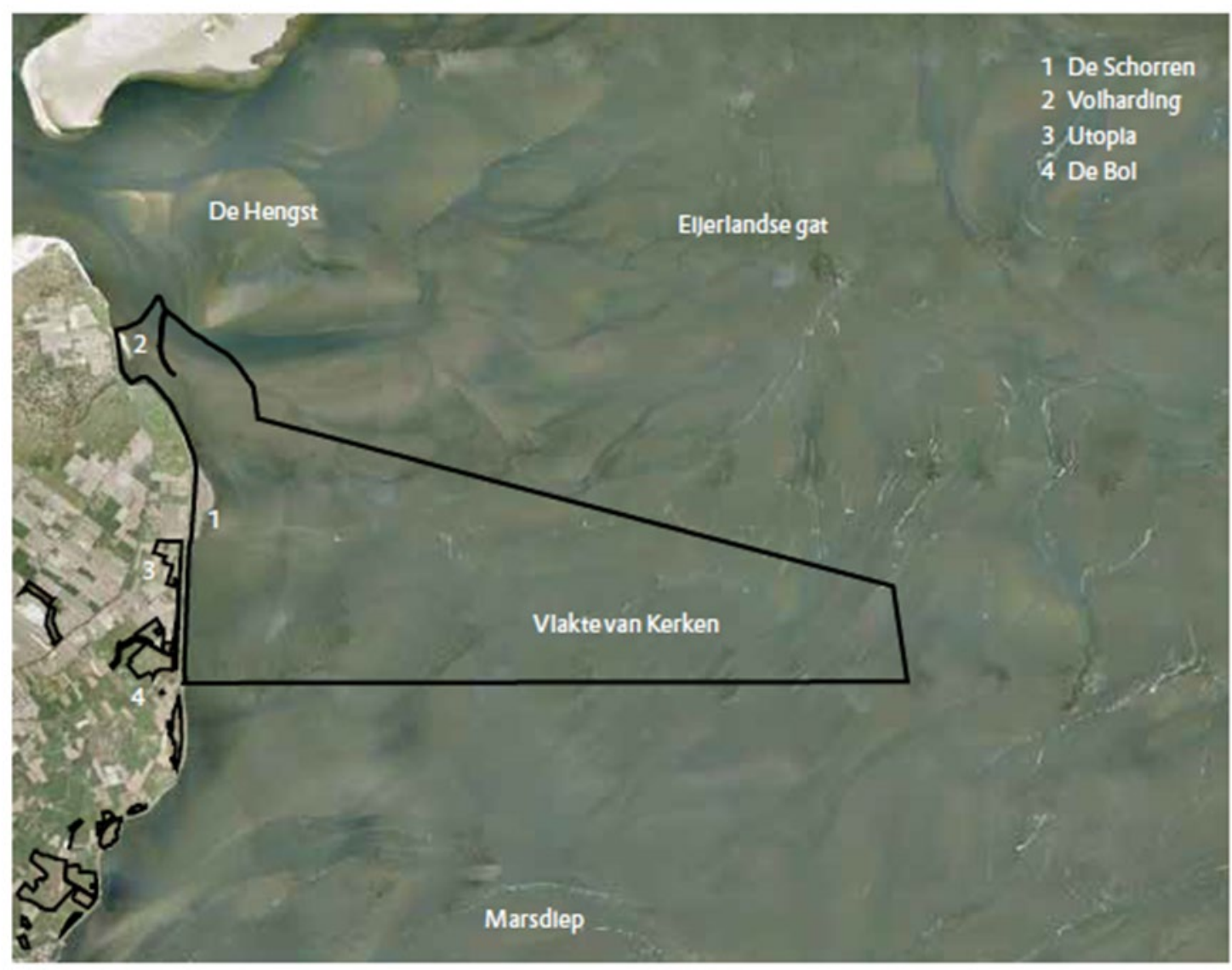

Figuur 3. Ligging van de Vlakte van Kerken met gebruikte toponiemen. 1: Volharding. 2: De Schorren (Bron: Nelis, Natuurmonumenten). 


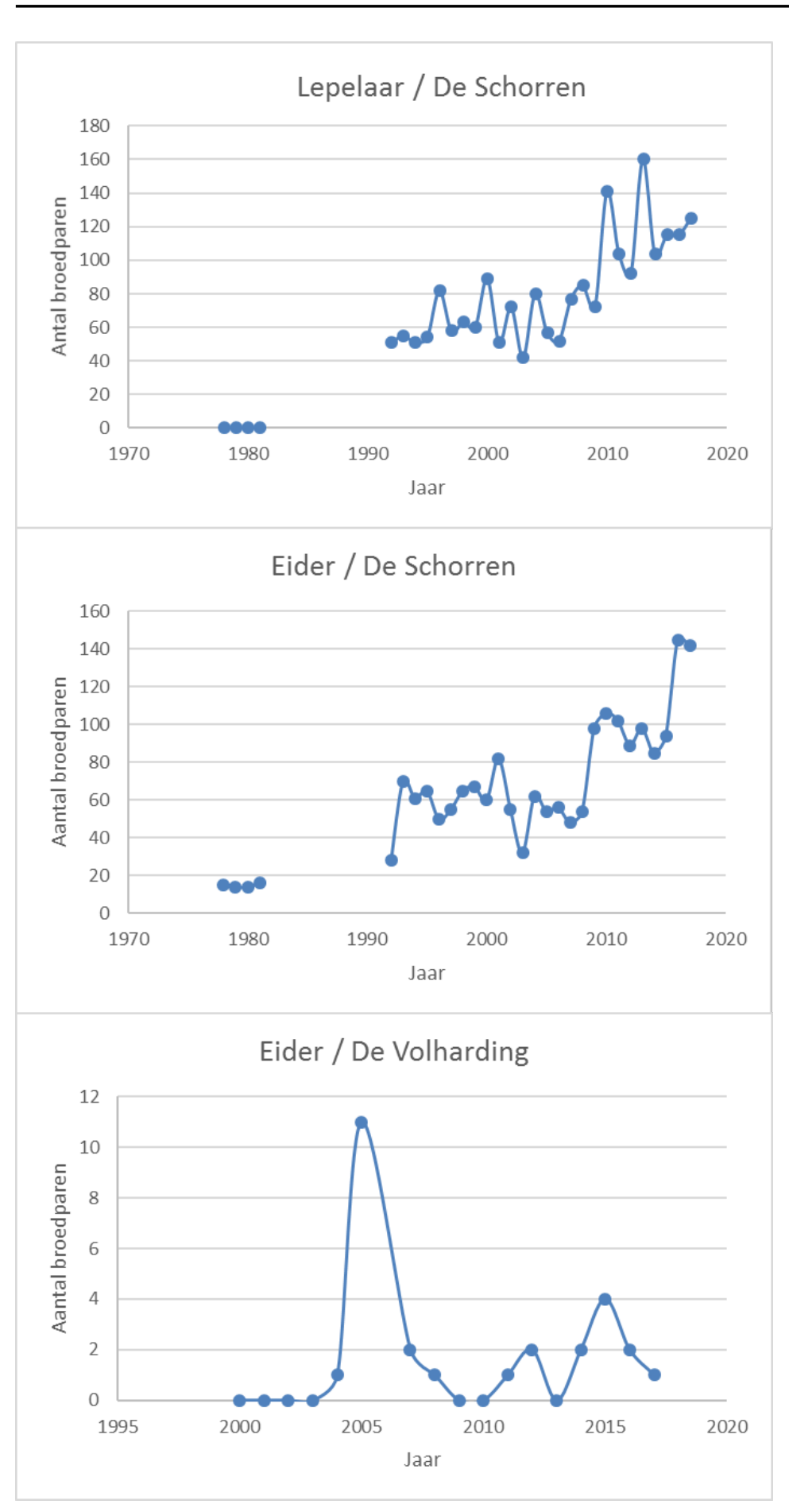

Figuur 4. Aantal broedparen van soorten met een instandhoudingsdoelstelling voor de Waddenzee die relevant zijn voor potentiele effecten van mechanische pierenwinning op de Vlakte van Kerken bij de Schorren en de Volharding. Bron: Natuurmonumenten (2018). 


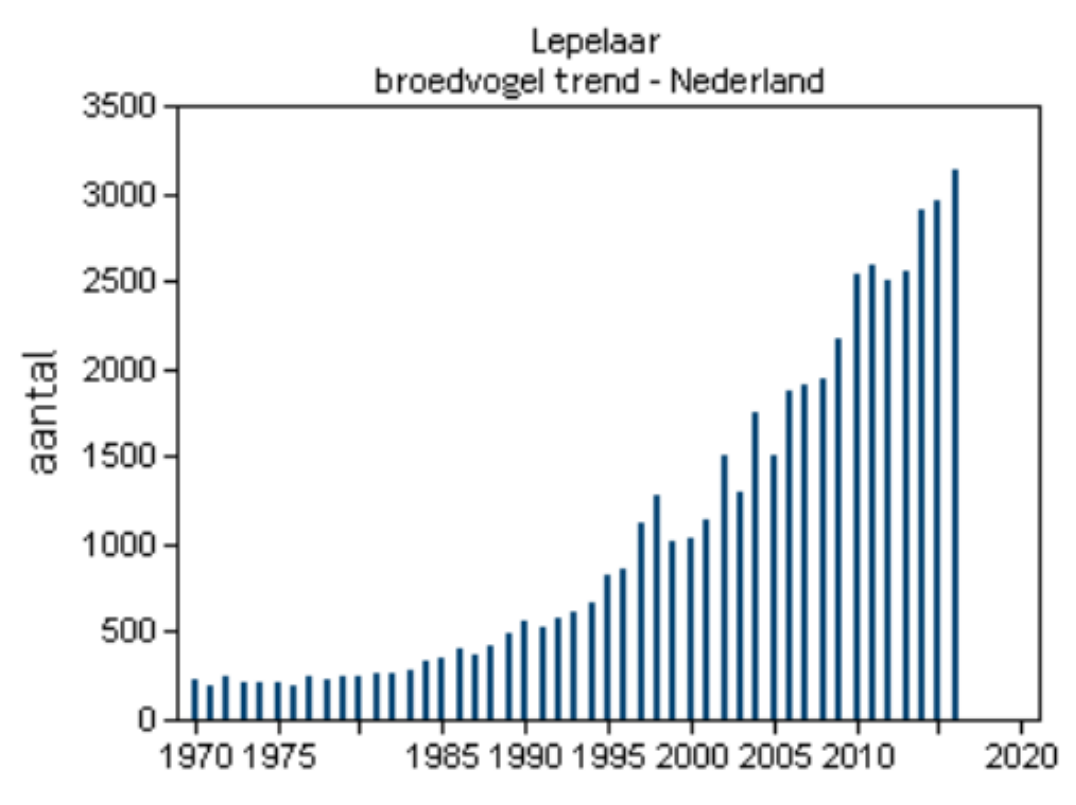

(9) NEM (Sovon, CBS, provincies), WL

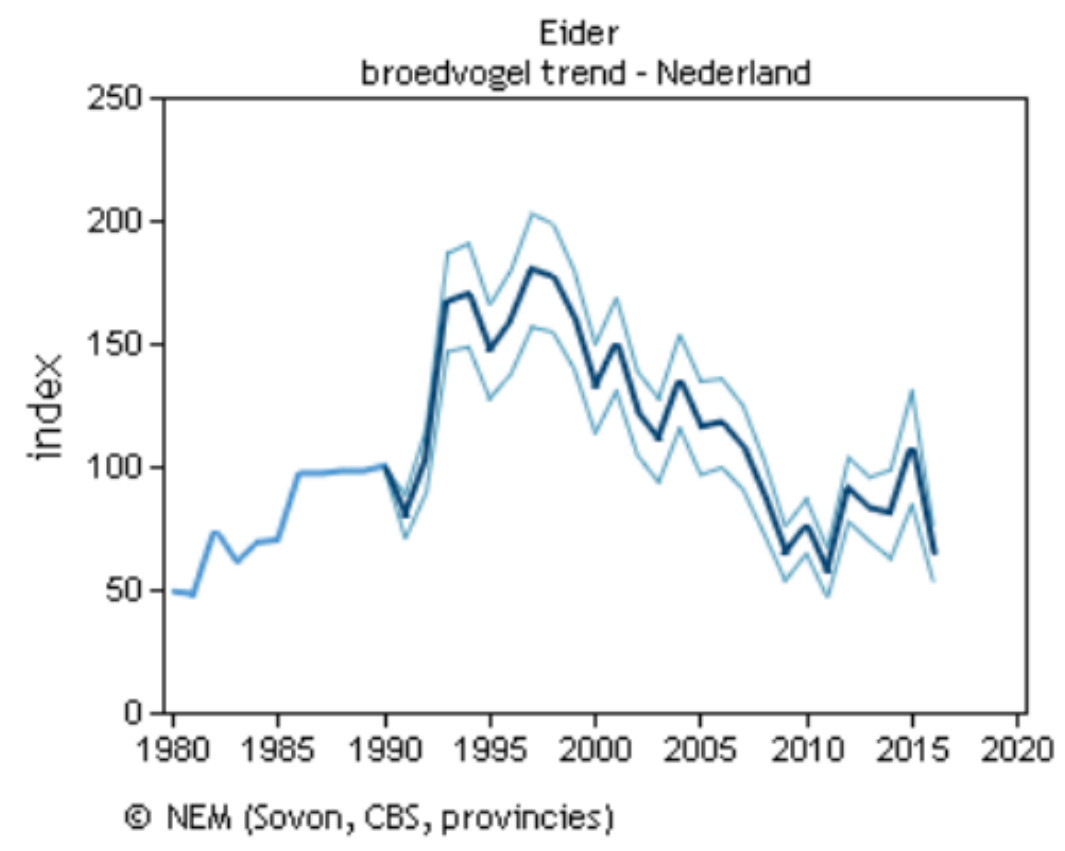

Figuur 5. Boven: Aantallen van de lepelaar en eider als broedvogel in Nederland. Deze grafiek is gebaseerd op het Meetnet Broedvogels (kolonies en zeldzame broedvogels). Onder: jaarlijkse populatie-index van eider, gebaseerd op de gehele populatie of aantallen in de belangrijkste broedgebieden. Bron: SOVON (www.sovon.nl/nl/soort/). 
Tabel 5. Aantal broedparen van soorten met een instandhoudingsdoelstelling voor de Waddenzee die bovendien relevant zijn voor potentiele effecten van mechanische pierenwinning op de Vlakte van Kerken bij de Schorren (A) en de Volharding (B). Bron: Natuurmonumenten (2018).

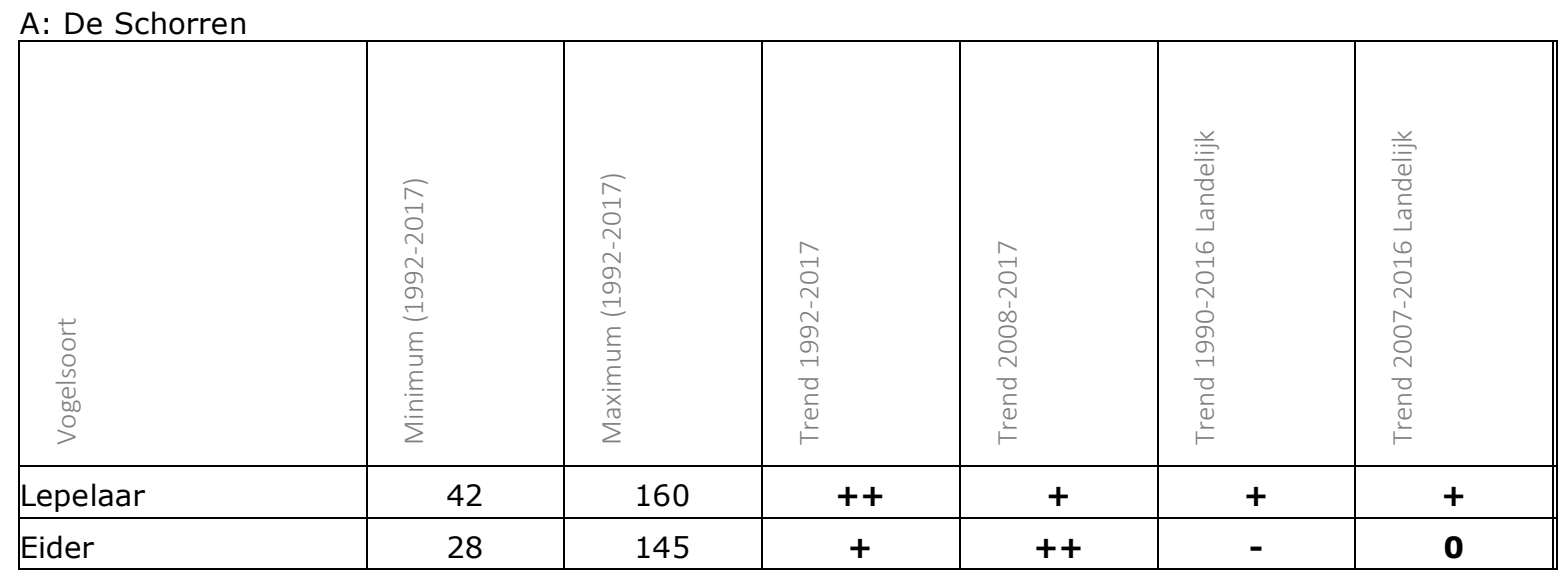

B: De Volharding

\begin{tabular}{|c|c|c|c|c|c|c|}
\hline 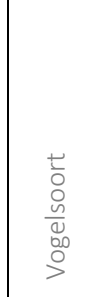 & 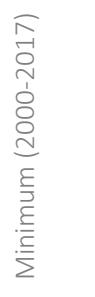 & 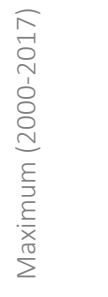 & 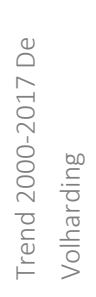 & 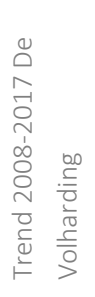 & 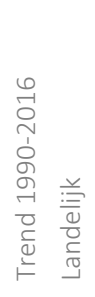 & 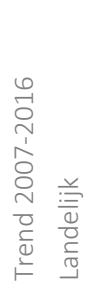 \\
\hline Eider & 0 & 11 & $\sim$ & $\sim$ & - & 0 \\
\hline
\end{tabular}

\section{Legenda}

Verklaring trend symbolen: ++ betekent sterk stijgend, + betekent stijgend, 0 betekent gelijk, - betekent dalend, -- betekent sterk dalend, betekent geen trend aantoonbaar. Rode lijst status afkortingen: $\mathrm{GE}=$ gevoelig, $\mathrm{KW}=$ kwetsbaar, $\mathrm{BE}=$ bedreigd, $\mathrm{EB}=$ ernstig bedreigd.

Er zijn nieuwe telgegevens van vogels op hoogwatervluchtplaatsen (HVPs) nabij De Schorren en Vlakte van Kerken in de beschikbaar gekomen (Natuurmonumenten 2015). Veel van de vogelsoorten op de HVPs hebben een instandhoudingsdoelstelling voor Natura 2000-gebied Waddenzee en zijn bovendien relevant voor de effectbeoordeling in verband met blootstelling aan mechanische pierenwinning op de Vlakte van Kerken. De ontwikkeling in de aantallen van deze vogelsoorten in de periode 1980-2011 staat vermeld in Tabel 6. Ter vergelijking is de trend in de gehele Waddenzee en de trend over Nederland ook in Tabel 6 gezet. Lepelaar en goudplevier hebben een sterk stijgende trend in analogie met de ontwikkeling in de gehele Waddenzee en in Nederland. De scholekster heeft in al deze gebieden een dalende trend. Tureluur en groenpootruiter blijven op hetzelfde niveau in alle gebieden. Zilverplevier, bonte strandloper, rosse grutto en wulp bleven gelijk in het telgebied, terwijl deze in de Waddenzee en/of landelijk een stijgende trend vertoonden. Daarentegen bleef de zwarte ruiter stabiel in het telgebied en de Waddenzee, maar nam deze landelijk sterk af. Er kan niet heel veel waarde worden toegekend aan de vergelijking van de trend in het telgebied nabij de Vlakte van Kerken t.o.v. trend in de gehele Waddenzee en de landelijk trend. De duur van de periode waarop de trends betrekking hebben is verschillend. Over de hele linie lijkt de aantalsontwikkeling in het telgebied en landelijk voor de meeste soorten redelijk vergelijkbaar en voor de andere soorten soms positiever en soms negatiever. Dit wijst niet duidelijk op een afname in kwaliteit van het gebied als foerageergebied voor de wadvogels en dit geeft ook geen aanwijzing dat er een duidelijke invloed van de mechanische pierenwinning op (rust)verstoring van vogels is geweest. 
Tabel 6. Gebruik van HVPs op en nabij De Schorren en Vlakte van Kerken (het "telgebied"). Bron: Natuurmonumenten (2015). Alleen de niet-broedvogelsoorten met een instandhoudingsdoelstelling voor Natura 2000-gebied Waddenzee en die relevant zijn in verband met blootstelling aan mechanische pierenwinning worden hier getoond.

\begin{tabular}{|c|c|c|c|c|c|c|c|}
\hline $\begin{array}{l}\text { Vogelsoort (vogelrichtlijnsoorten (niet- } \\
\text { broedvogels) relevant voor de Waddenzee) }\end{array}$ & 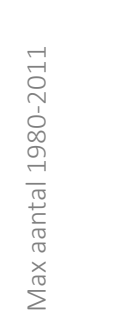 & 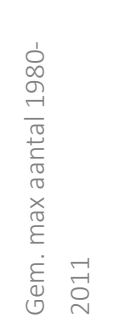 & 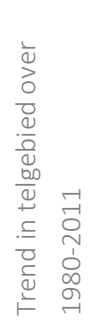 & 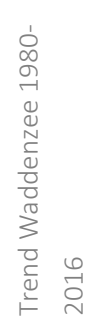 & 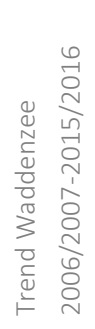 & 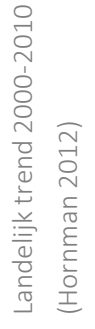 & 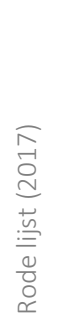 \\
\hline A034 - Lepelaar & 496 & 166 & ++ & ++ & + & ++ & \\
\hline A048 - Bergeend & & & & + & + & & \\
\hline A063 - Eider & & & & - & - & & \\
\hline A067 - Brilduiker & & & & - & - & & GE \\
\hline A130 - Scholekster & 20830 & 3947 & - & - & - & - & \\
\hline A140 - Goudplevier & 6040 & 3275 & ++ & + & $\sim$ & ++ & \\
\hline A141 - Zilverplevier & 1424 & 764 & 0 & + & 0 & + & \\
\hline A143 - Kanoet & 28040 & 1604 & $?$ & + & + & 0 & \\
\hline A149 - Bonte strandloper & 7772 & 2186 & 0 & + & 0 & 0 & \\
\hline A157 - Rosse grutto & 12741 & 12994 & 0 & + & 0 & + & \\
\hline A160 - Wulp & 9814 & 3084 & 0 & + & 0 & + & $\mathrm{KW}$ \\
\hline A161 - Zwarte ruiter & 470 & 14 & 0 & 0 & $\sim$ & -- & \\
\hline A162 - Tureluur & 5155 & 828 & 0 & 0 & 0 & 0 & GE \\
\hline A164 - Groenpootruiter & 1500 & 186 & 0 & 0 & 0 & 0 & \\
\hline
\end{tabular}

Legenda

GE: gevoelig; KW: kwetsbaar

Aantallen getelde vogels in telgebieden op en nabij de Vlakte van Kerken: De Schorren en polder Eendracht (telgebied 8), Polder Wassenaar, De Volharding en Zeeburg (telgebied 9) en polder het Noorden, inclusief de Bol en Utopia (telgebied 22).

\subsubsection{Verstoring}

$\mathrm{Er}$ is geen aanvullende informatie beschikbaar over een direct zichtbare verstoring van vogels door de mechanische pierenwinning. NB: de winning vindt plaats tijdens hoogwater, als de steltlopers zich op de HVPs bevinden, en niet in het concessiegebied.

\subsubsection{Voedselbeschikbaarheid}

Voor mechanische pierenwinning op de Vlakte van Kerken is een gebied vergund van 1737 ha. In de rapportage van Leopold en Bos (2009) is berekend dat in dit gebied jaarlijks 27 ha wordt gebruikt. Dit is $0,03 \%$ van het oppervlakte habitattype 1140 in de Nederlandse Waddenzee. Wanneer wordt uitgegaan van een hersteltijd van 2 jaar voor de voorkomende wormen, dan bedraagt dit 0,06\% van het oppervlakte habitattype 1140 in de Nederlandse Waddenzee. Wanneer wordt uitgegaan van een hersteltijd van 5 jaar voor de langlevende en langzaam herstellende schelpdieren als de strandgaper, dan wordt 0,15\% van het oppervlakte habitattype 1140 in de Nederlandse Waddenzee beïnvloed (FeyHofstede \& Smit, 2009). 
Tabel 7. Oppervlakte mechanische pierenwinning door Arenicola B.V. ten opzichte van totaal oppervlakte habitattype 1140 in de Nederlandse Waddenzee.

\begin{tabular}{|l|l|l|}
\hline Gebiedsomschrijving & $\begin{array}{l}\text { Oppervlakte } \\
\text { activiteit }\end{array}$ & $\begin{array}{l}\text { Percentage van } \\
\text { H1140 in de } \\
\text { Waddenzee }\end{array}$ \\
\hline Pierenwingebieden Arenicola B.V. & $\begin{array}{l}1737 \text { ha, waarvan } \\
1500 \text { ha werkbaar }\end{array}$ & $\begin{array}{l}1,9 \% \\
1,6 \%\end{array}$ \\
\hline Daadwerkelijk beviste gebied Arenicola B.V. & 27 ha & $0,03 \%$ \\
\hline $\begin{array}{l}\text { Schatting mogelijk aangetast gebied bij een hersteltijd } \\
\text { van } 2 \text { jaar }\end{array}$ & 54 ha & $0,06 \%$ \\
\hline $\begin{array}{l}\text { Schatting mogelijk aangetast gebied bij een hersteltijd } \\
\text { van } 3 \text { jaar }\end{array}$ & 81 ha & $0,09 \%$ \\
\hline $\begin{array}{l}\text { Schatting mogelijk aangetast gebied bij een hersteltijd } \\
\text { van } 5 \text { jaar }\end{array}$ & 135 ha & $0,15 \%$ \\
\hline
\end{tabular}

\subsubsection{Conclusie}

De werkwijze van de mechanische pierenwinning is sinds 2009 gehandhaafd. Er zijn nieuwe monitoringsgegevens van de bodemfauna van het beviste gebied beschikbaar gekomen, waaruit blijkt dat de bodemfauna in het beviste gebied niet aantoonbaar negatief is beïnvloed door de mechanische pierenvisserijactiviteiten. Het is daarom aannemelijk dat de kwaliteit van het gebied als foerageergebied voor vogels niet aantoonbaar negatief is beïnvloed door de mechanische pierenvisserijactiviteiten. Dit is een bevestiging van de redenering in de PB-2009.

De conclusies over de mogelijke effecten op vogelrichtlijnsoorten van het mechanisch winnen van pieren op de Vlakte van Kerken veranderen dus niet ten opzichte van die van de vorige PB (FeyHofstede \& Smit, 2009). Onderstaande tabel geeft die conclusies beknopt weer.

\begin{tabular}{|c|c|}
\hline Vogelsoorten & $\begin{array}{l}\text { Relevante vogelrichtlijnsoorten (A034 lepelaar, A048 bergeend, A063 eider, } \\
\text { A067 brilduiker, A140 goudplevier, A141 zilverplevier, A143 kanoet, A149 } \\
\text { bonte strandloper, A157 rosse grutto, A160 wulp, A161 zwarte ruiter, A162 } \\
\text { tureluur, A164 groenpootruiter) }\end{array}$ \\
\hline EFFECTEN & $\begin{array}{l}\text { Mogelijke effecten op voedselbeschikbaarheid of verstoring tijdens het } \\
\text { voedsel zoeken (bij hoogwater). }\end{array}$ \\
\hline MITIGATIE & $\begin{array}{l}\text { Duurzame werkwijze, activiteit vindt alleen bij hoogwater plaats, lokale aard } \\
\text { en beperkte omvang, tijdens het winnen wordt niet sneller gevaren dan } 2-4 \\
\text { meter/minuut, er wordt niet gewonnen op locaties met hoge dichtheden } \\
\text { kokkels (>600 kokkels/m2) en de gehanteerde voorwaarde dat broedende } \\
\text { vogels, rustende en/of ruiende vogelgroepen niet dichter dan tot op een } \\
\text { afstand van } 500 \mathrm{~m} \text { mogen worden genaderd. }\end{array}$ \\
\hline $\begin{array}{l}\text { MATE VAN } \\
\text { VERSTORING C.Q. } \\
\text { VERSLECHTERING }\end{array}$ & $\begin{array}{l}\text { Gezien de duurzame werkwijze van Arenicola B.V., de lokale aard, omdat de } \\
\text { bodemfauna in het beviste gebied niet aantoonbaar negatief wordt beïnvloed, } \\
\text { er alleen gewonnen wordt tijdens hoogwater, er vogelsoorten foerageren in } \\
\text { de zeer dichte nabijheid van het winschip (Leopold 2002) en gezien de } \\
\text { mitigerende maatregelen die worden genomen, zal mechanische } \\
\text { pierenwinning in de concessiegebieden op de Vlakte van Kerken door } \\
\text { Arenicola B.V. naar verwachting niet leiden tot significante aantasting van de } \\
\text { relevante vogelrichtlijnsoorten als wezenlijk kenmerk van het beschermde } \\
\text { gebied. }\end{array}$ \\
\hline
\end{tabular}




\begin{tabular}{|l|l|}
\hline Vogelsoorten & Scholekster \\
\hline EFFECTEN & Mogelijke effecten op voedselbeschikbaarheid \\
\hline MITIGATIE & $\begin{array}{l}\text { Duurzame werkwijze, de matige kwaliteit van het gebied rond het } \\
\text { concessiegebied als voedselgebied voor scholeksters, het niet winnen } \\
\text { op locaties met hoge dichtheden kokkels ( }>600 \mathrm{kokkels} / \mathrm{m}^{2} \text { ) en } \\
\text { gehanteerde voorwaarde dat broedende vogels, rustende en/of } \\
\text { ruiende vogels bij de visserijactiviteiten niet dichter dan tot op een } \\
\text { afstand van } 500 \text { m mogen worden genaderd. }\end{array}$ \\
\hline MATE VAN VERSTORING & $\begin{array}{l}\text { Gezien de matige kwaliteit van de concessiegebieden als } \\
\text { voedselgebied voor scholeksters, omdat de bodemfauna in het } \\
\text { beviste gebied niet aantoonbaar negatief wordt beïnvloed, en gezien } \\
\text { de mitigerende maatregel om niet te winnen op locaties in het } \\
\text { concessiegebied met kokkels in dichtheden }>600 \text { kokkels/m }{ }^{2} \text { of op } \\
\text { mosselbanken, wordt geen significant negatief effect verwacht op de } \\
\text { draagkracht van de Waddenzee of specifiek de Vlakte van Kerken } \\
\text { voor de populatie scholeksters. }\end{array}$ \\
\hline
\end{tabular}

\subsection{Belangrijke afwegingen in verband met het Beschermd Staatsreservaat Waddenzee en het Beschermd natuurmonument Schorren van de Eendracht}

Hiervoor is geen aanvullende informatie beschikbaar. Wat in de PB-2009 hierover wordt vermeld, blijft gehandhaafd. In de PB-2009 werd het volgende vermeld. Met de inwerkingtreding van de Natuurbeschermingswet 1998 verviel het onderscheid tussen Staats- en Beschermde Natuurmonumenten, beide worden nu Beschermde Natuurmonumenten genoemd. Daarnaast komen die (delen van) Natuurmonumenten die overlappen met Natura 2000-gebieden te vervallen. De instandhoudingsdoelstellingen van het betreffende Natura 2000-gebied zullen wel mede betrekking hebben op de waarden die beschermd werden door het Natuurmonument. Deze waarden betreffen vooral natuurschoon en natuurwetenschappelijke betekenis. In verband met deze aanwijzing is in de PB-2009 extra aandacht geschonken aan duisternis, natuurschoon en ongereptheid. Daarin werd geconcludeerd dat er geen significante verstoring van de duisternis in de Waddenzee zal optreden en lokale beïnvloeding van het natuurschoon en de ongereptheid beperkter zal zijn dan de eventuele effecten op instandhoudingsdoelen van Natura 2000-gebied Waddenzee. 


\section{$6 \quad$ Mitigatie}

De werkwijze van Arenicola B.V. (zie bijlage 1) en het volgen van de voorschriften bij de Nbwetvergunning zorgen voor voldoende mitigatie van mogelijk negatieve effecten op de beschermde natuurwaarden. 


\section{$7 \quad$ Cumulatie}

Cumulatieve effecten van mechanische pierenwinning op de Vlakte van Kerken kunnen zich voordoen door interactie met wadpierenvisserij op andere locaties in hetzelfde habitattype (H1140 van de Nederlandse Waddenzee) en door interactie van mechanische pierenwinning met ander gebruik in de nabijheid van het concessiegebied voor pierenwinning op de Vlakte van Kerken.

\subsection{Cumulatie door meerdere pierenwinlocaties}

De mechanische pierenvisserij op de Waddenzee vindt behalve op concessiegebied de Vlakte van Kerken bij Texel door vergunninghouder Arenicola B.V. ook plaats op concessiegebied Balgzand/Breehorn en Middelplaat, zie Figuur 6) door vergunninghouder Rotgans (Gedeputeerde Staten provincie Noord-Holland, 2010b). Het totaal vanaf 2010 vergunde areaal waar mechanisch pieren worden gewonnen in het Natura 2000-gebied Waddenzee is circa 3106 ha (1737 ha oostelijk van Texel en 1369 ha op Balgzand/Breehorn en Middelplaat, beide na aftrek van de niet benutbare geulen). Dit is ca. 3,1\% van het areaal van habitattype droogvallende platen (90725 ha) in de hele Waddenzee. Door de twee bedrijven wordt elk maximaal $75 \mathrm{ha} /$ jaar gevist. Dat is voor de bedrijven samen 150 ha/jaar van het in totaal ca. 2869 ha grote concessiegebied, hetgeen jaarlijks maximaal ca. $0,17 \%$ (van het oppervlak van H1140A in de Waddenzee daadwerkelijk beïnvloed (Gedeputeerde Staten Provincie Noord-Holland (2010a en 2010b; Jongbloed \& Tamis, 2011). Het oppervlak van $\mathrm{H} 1140$ dat op enige wijze aangetast gebied is bij een hersteltijd van 5 jaar is 750 ha en dat is een relatief aandeel van 0,83\%. Door Fey-Hofstede \& Smit (2009) werd geconcludeerd dat door de lokaliteit van de activiteiten en de afstand tussen de activiteiten redelijkerwijs geen cumulatief significante gevolgen worden verwacht met betrekking tot de relevante natuurkenmerken van het Natura 2000-gebied Waddenzee. Doordat er, voor zo ver bekend, tussen 2010 en 2018 geen hogere visserijdruk bij beide concessiehouders is opgetreden, kan hier de conclusie van Fey-Hofstede \& Smit (2009) worden aangehouden. 


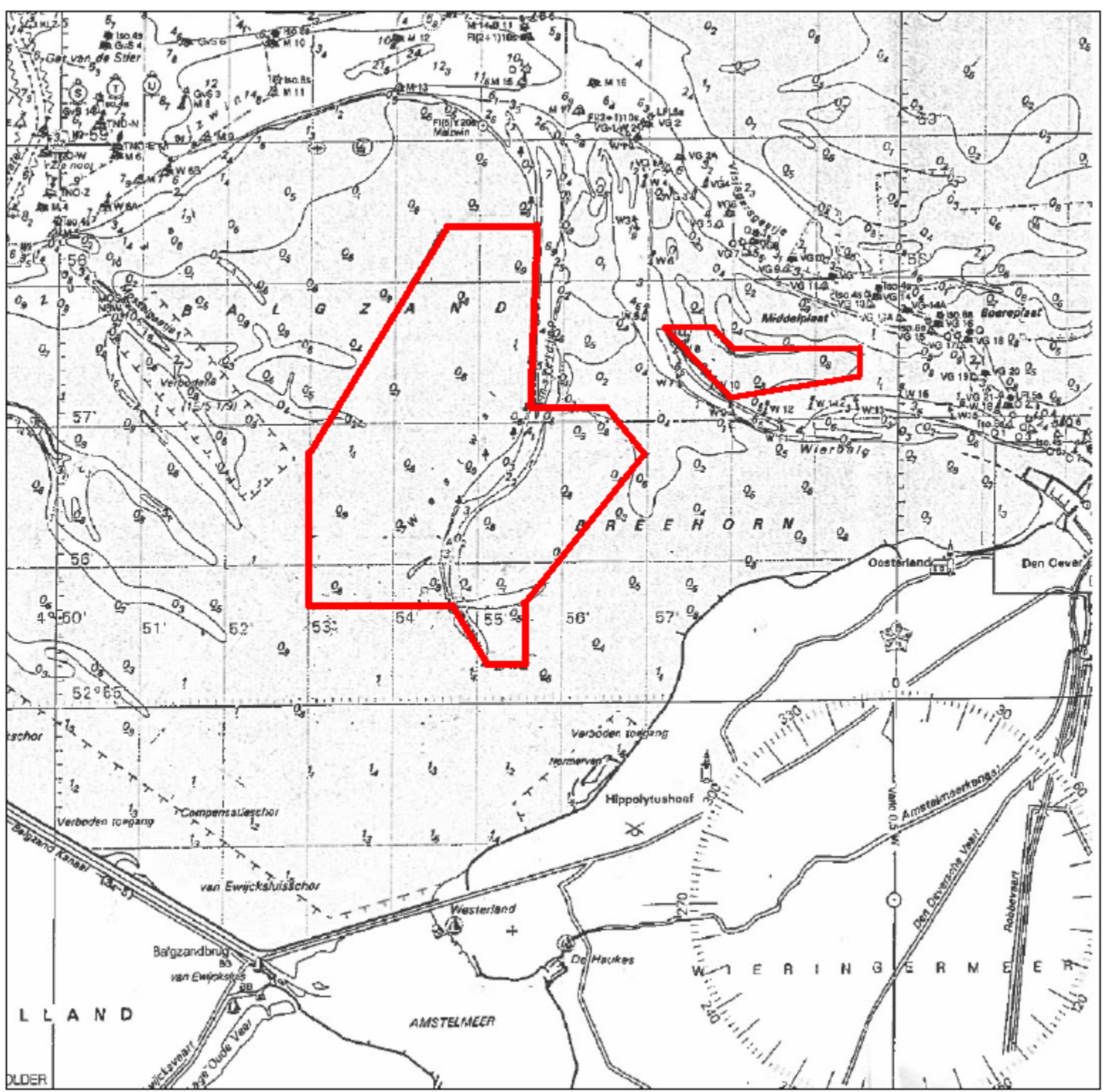

Figuur 6. Concessiegebieden van de fa. Rotgans op het Balgzand en de Middelplaat (ingetekende gebieden).

\subsection{Cumulatie door andere activiteiten}

Fey-Hofstede \& Smit (2009) merkten reeds op dat er in de Waddenzee naast mechanische pierenwinning andere menselijke activiteiten zijn die effecten hebben op bodemgesteldheid (H1140), voedselbeschikbaarheid voor vogels en verstoring. Zij verwijzen hierbij naar de eerste resultaten uit de Nader Effecten Analyse (NEA) voor de Natura 2000- instandhoudingsdoelstellingen van de Waddenzee die werd uitgevoerd in opdracht van Rijkswaterstaat. Het definitieve deelrapport over de cumulatieve effecten (Jongbloed et al. 2011) is verschenen na de PB-2009 en de Nb-wetvergunning (Gedeputeerde Staten Noord-Holland, 2010a). In Tabel 8 staan de activiteiten die relevant zijn in combinatie met mechanische pierenwinning. Er zijn ten opzichte van de PB-2009 een 7-tal extra activiteiten die via verstoring bijdragen (kleine effect) aan cumulatie en één extra activiteit die via voedselbeschikbaarheid bijdraagt (klein effect) aan cumulatie. 
Tabel 8. Activiteiten, waaronder mechanische pierenwinning, die voorkomen op H1140 in de Waddenzee (Jongbloed et al. 2011). Daarbij is aangegeven ( $x$ ) of de activiteit mogelijk effect heeft op dezelfde aspecten als mechanische pierenwinning. NB: Garnalenvisserij mag alleen worden uitgeoefend in het sublitoraal (H1110); de bodemberoering daarvan treedt niet op in $\mathrm{H1140.}$

\begin{tabular}{|c|c|c|c|c|c|}
\hline Activiteiten & 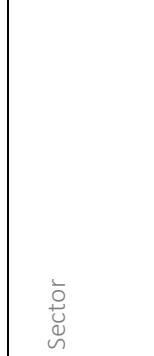 & 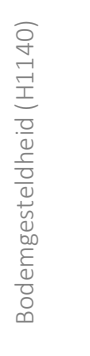 & 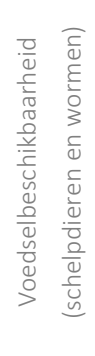 & 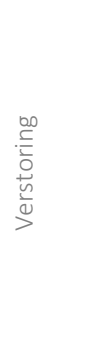 & 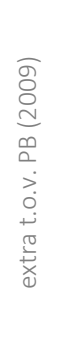 \\
\hline Mechanische pierenwinning & Visserij & $x$ & $x$ & $x$ & \\
\hline Zee-aas steken & Visserij & $x$ & $x$ & $x$ & \\
\hline Rapen voor eigen gebruik & Visserij & & $x$ & $x$ & \\
\hline Handkokkelen & Visserij & $x$ & $x$ & $x$ & \\
\hline Garnalenvisserij & Visserij & & & $\mathrm{x}$ & \\
\hline Mosselzaadvisserij & Visserij & & $x$ & $\mathrm{x}$ & $\underline{x}$ \\
\hline Mosselkweekpercelen & Visserij & & & $x$ & $x$ \\
\hline Waterrecreatie & Recreatie & & & $x$ & \\
\hline \begin{tabular}{|l|} 
Evenementen \\
\end{tabular} & Recreatie & & & $x$ & \\
\hline Bivakkeren op zandplaten & Recreatie & $x$ & & $x$ & $\underline{x}$ \\
\hline Droogvallen & Recreatie & $x$ & & $\mathrm{x}$ & $\underline{x}$ \\
\hline Scheepvaart & Overig & & & $\mathrm{x}$ & \\
\hline Luchtvaart & Overig & & & $x$ & $\underline{x}$ \\
\hline $\begin{array}{l}\text { Onderhoud kwelders (openstelling } \\
\text { voor recreanten) }\end{array}$ & Overig & & & $x$ & $x$ \\
\hline
\end{tabular}

Uit Tabel 8 blijkt dat verstoring het meest voorkomende effect is in het Natura 2000-gebied.

Pierenvissen draagt daar niet significant aan bij omdat de activiteit tijdens hoogwater plaatsvindt. De invloed van mechanische pierenwinning op de bodemgesteldheid (H1140) en de voedselbeschikbaarheid voor vogels is beschreven in de effectenanalyse van de PB-2009. De door de aanvrager aangevraagde activiteit is een dusdanig kleinschalige activiteit in vergelijking met het Natura 2000-gebied (H1140) en de andere aanwezige activiteiten dat redelijkerwijs niet te verwachten is dat deze activiteit de mogelijke effecten van andere reeds bestaande activiteiten met betrekking tot de relevante natuurkenmerken van het Natura 2000-gebied Waddenzee zal versterken.

Met het bovenstaande kan worden geconcludeerd dat de bijdrage van de mechanische pierenwinning in de concessiegebieden op de Vlakte van Kerken aan de cumulatie van effecten als niet significant kan worden beschouwd. Deze conclusie komt overeen met die van Fey-Hofstede \& Smit (2009). 


\section{$8 \quad$ Alternatieven voor mechanische pierenwinning}

In de PB van Fey-Hofstede \& Smit (2009) is beschreven dat handmatig pierenspitten en import en kweek van wadpieren geen reëel alternatief voor mechanische pierenwinning zijn. NB: handmatig spitten vindt plaats tijdens laagwater en is veel minder effectief dan mechanisch pieren winnen oftewel, er wordt meer oppervlakte gebruikt en er worden meer vogels verstoord. Voor de hoeveelheid pieren die het ene schip van Arenicola opvist, zou een zeer groot aantal spitters nodig zijn. De verstoring door handmatig spitten zou daarom, en ook omdat spitten bij laagwater gebeurt, vele malen ernstiger zijn met betrekking tot verstoring van wadvogels dan van mechanische winning.

Het Programma Rijke Waddenzee is vanaf 2016 gestart met een initiatief "Waddenzee vrij van mechanische pierenwinning". Dit initiatief is in januari 2019 afgesloten met een rapportage van Michiel Firet. In dit rapport wordt de verwachting uitgesproken dat: "de wadpieren niet of nauwelijks [zijn] over te bevissen [en dat] vanuit dat oogpunt de activiteit dus bestendig [is]". Firet (2019) stelt verder dat de kweek van wadpieren, als alternatief voor de pierenvisserij, weliswaar technisch mogelijk is, maar dat bedrijfseconomisch het maar de vraag is of het rendabel gemaakt kan worden. Firet (2019) concludeert ook dat de marktvraag naar wadpieren, als aas in de sportvisserij, zal blijven bestaan. Het meest logische scenario is daarom dat de pierenvisserij in de huidige vorm zal blijven bestaan, ook al omdat het verplaatsen en/of vergroten van deze activiteit binnen de natuurbeschermingswet geen optie is. Aanvoer van wadpieren uit het buitenland lijkt evenmin een haalbare kaart. In Duitsland is er nooit op een vergelijkbare manier op wadpieren gevist als in het Nederland, maar met behulp van draaiende buitenboordmotoren vlak boven of deels in de zandbodem. Commercieel is deze activiteit, evenals handspitten, al heel veel jaren verboden. In Denemarken was er, tot omstreeks 15 jaar geleden, wel een pierenvisserij met enigszins vergelijkbare schepen als in Nederland. Denemarken heeft net als Duitsland, met handspitters de markt bediend. Door de daling van het aantal handspitters is er steeds vraag gekomen naar import-kweekzagers (Alitta virens)uit Nederland en Engeland en zagers uit China (Perinereis aibuhitensis, determinatie Marc Lavaleye). Een deel van deze import betreft dus een exoot.

Het door sportvissers, ook als alternatief gebruikte, kunstaas veroorzaakt een extra opeenstapeling van onverteerbaar afval op wad- en zeebodem. 


\section{$9 \quad$ Conclusies en aanbevelingen}

In het onderhavige rapport zijn de volgende aanvullingen ten opzichte van de PB van Fey-Hofstede $\&$ Smit (2009) meegenomen:

1. De werkwijze van mechanische pierenwinning door Arenicola B.V. is op twee puntenaangepast: de maximale diepte van de graver is verminderd van $40 \mathrm{~cm}$ naar $35 \mathrm{~cm}$ en de nauwkeurigheid van navigatie is verbeterd van $50 \mathrm{~cm}$ naar $0,5 \mathrm{~cm}$.

2. De vangstefficiëntie (CPUE) is toegenomen: opbrengst aan pieren per liter brandstof van de mechanische pierenwinning door Arenicola B.V is toegenomen.

3. Veranderingen van de instandhoudingsdoelstellingen van habitattype, habitatsoorten en vogelsoorten waaraan getoetst moet worden.

4. Ontwikkelingen in de dichtheid en samenstelling van de bodemfauna in het winningsgebied aangetoond met monitoring.

5. Ontwikkelingen van aantallen van potentieel gevoelige vogelsoorten in en nabij het winningsgebied d.m.v. telgegevens in en nabij het wingebied.

Er is geen nieuwe volledige PB uitgevoerd. De PB van 2009 blijft de basis. De bovengenoemde aanvullingen worden wel betrokken in de effectbeoordeling. Aanvulling nummer 3 heeft geen consequenties voor de beoordeling. Aanvulling nummer 4 geeft een betere onderbouwing van de toelaatbaarheid van de activiteit in het gebied, omdat er tussen het beviste gebeid en het niet-beviste gebied (referentiegebied) geen significante verschillen in de dichtheid en samenstelling van de bodemfauna in het winningsgebied zijn gevonden. Aanvulling nummer $5 \mathrm{geeft}$ extra aanwijzingen dat vogelsoorten niet of niet noemenswaardig negatief worden beïnvloed door mechanische perenwinning.

De aanvullingen bevestigen de conclusies uit de PB-2009. Van de aangevraagde activiteit wordt geen significante aantasting verwacht van het habitattype 1110 en 1140, relevante habitatrichtlijnsoorten of vogelrichtlijnsoorten als wezenlijk kenmerk van het beschermde gebied Natura 2000-gebied Waddenzee en Natura 2000-gebied Duinen en Lage Land Texel.

De aanvullende gegevens uit dit rapport ondersteunen de conclusie van de PB-2009 en de begeleidende memo (Fey-Hofstede \& Smit 2009\#) naar aanleiding van vragen en opmerkingen van provincie Noord-Holland (d.d. 19-11-2009) naar aanleiding van de PB. Deze conclusie is dat gezien de duurzame werkwijze van Arenicola B.V., de lokale aard, de geringe mate van aantoonbare schade en het herstelvermogen van de bodemdiersoorten, zoals blijkt uit het sinds 2008 uitgevoerde monitoringsprogramma, dat er alleen gewonnen wordt tijdens hoogwater, er vogelsoorten foerageren in de zeer dichte nabijheid van het winschip (Leopold 2002) en gezien de mitigerende maatregelen die worden genomen, zal mechanische pierenwinning in de concessiegebieden op de Vlakte van Kerken door Arenicola B.V. naar verwachting niet leiden tot significante aantasting van de relevante vogelrichtlijnsoorten als wezenlijk kenmerk van het beschermde gebied en de van dit gebied geformuleerde instandhoudingsdoelen niet negatief beïnvloeden.

Naast de lokale en beperkte omvang zullen ook mitigerende maatregelen getroffen worden om de effecten op vogels en zeehonden tot een minimum te beperken. Het is tevens onwaarschijnlijk dat de aangevraagde activiteiten de eventuele effecten van andere projecten of activiteiten op de relevante natuurwaarden zal versterken. 


\section{Kwaliteitsborging}

Wageningen Marine Research beschikt over een ISO 9001:2015 gecertificeerd kwaliteitsmanagementsysteem. Dit certificaat is geldig tot 15 december 2021. De organisatie is gecertificeerd sinds 27 februari 2001. De certificering is uitgevoerd door DNV GL. 


\section{Literatuur}

Beukema J.J. (1995) Long-term effects of mechanical harvesting of lugworms Arenicola marina on the zoobenthic community of a tidal flat in the Wadden Sea. Netherlands Journal of Sea Research 33: 219227.

Beukema, J.J., E.C. Flach, R. Dekker, M. Starink (1999) A long-term study of the recovery of the macrozoobenthos on large defaunated plots on a tidal flat in the Wadden Sea. Journal of Sea Research 42: 235-254.

Brasseur S., Czeck R., Galatius A., Fast Jensen L., Jeß A., Körber P., Pund R., Siebert U., Teilmann J. \& Klöpper S. (2017) TSEG Grey Seal surveys in the Wadden Sea and Helgoland in 2016-2017. Report Common Wadden Sea Secretariat, www.waddenseasecretariat.org/sites/default/files/CWSS_Internal/TMAP/Marine_Mammals/17-0607_greysealreport2017.pdf

Compton T.J., S. Holthuijsen, A. Koolhaas, A. Dekinga, J. ten Horn, J. Smith, Y. Galema, M. Brugge, J. van der Meer, H.W. van der Veer, T. Piersma (2012) Synoptic intertidal benthic surveys across the Dutch Wadden Sea Report on data collected from 2008 to 2010 . NIOZ rapport 2012-1. http://www.nioz.nl/files/afdelingen/Bibliotheek/NIOZ\%20rapporten/niozreport_ 2012-1.pdf

Compton T.J., S. Holthuijsen, A. Koolhaas, A. Dekinga, J. ten Horn, J. Smith, Y. Galama, M. Brugge, D. van der Wal, J. van der Meer, H.W. van der Veer, T. Piersma (2013) Distinctly variable mudscapes: Distribution gradients of intertidal macrofauna across the Dutch Wadden Journal of Sea Research http://dx.doi.org/10.1016/j.seares.2013.02.002

Drent, J. (2013) Monitoring van effecten op de bodemfauna door wadpierenvisserij op de Vlakte van Kerken in de periode 2008-2011. NIOZ intern rapport.

Drent, J. (2015) Monitoring van effecten van wadpierenvisserij op de bodemfauna van de Vlakte van Kerken in de periode 2012-2014. NIOZ intern rapport.

Fey-Hofstede, F. en C.J. Smit (2009\#) Memo met reactie naar aanleiding van vragen en opmerkingen (d.d. 19-11-2009) naar aanleiding van de Passende Beoordeling mechanische winning van pieren door Arenicola B.V. op de Vlakte van Kerken (IMARES C112/09. Memo van 3 december 2009 gericht aan Mevrouw M. Doevendans, Provincie Noord-Holland. Directie Subsidies, Handhaving en Vergunningverlening, Unit Vergunningen Omgeving.

Fey-Hofstede, F. en C.J. Smit (2009) Passende beoordeling mechanische winning van pieren door Zeeaashandel Arenicola op de Vlakte van Kerken (Waddenzee). IMARES rapport C112/09.

Gedeputeerde Staten Provincie Noord-Holland (2010a): Nb-wet vergunning voor het mechanisch winnen van wadpieren binnen het concessiegebied "Vlakte van Kerken" voor Arenicola B.V. gevestigd te Oosterend (gemeente Texel).

Firet, M. (2019) Pierenwinning en een Rijke Waddenzee. Advies vervolg PRW-initiatief Waddenzee vrij van mechanische pierenwinning. https://rijkewaddenzee.nl/wp-content/uploads/2019/11/190130Pierenwinning-en-een-Rijke-Waddenzee-def.pdf

Gedeputeerde Staten Provincie Noord-Holland (2010a) Nb-wet vergunning voor het mechanisch winnen van wadpieren binnen het concessiegebied "Vlakte van Kerken" voor Arenicola B.V. gevestigd te Oosterend (gemeente Texel). Gedateerd 30 april 2010. 
Gedeputeerde Staten Provincie Noord-Holland (2010b) Nb-wet vergunning voor het mechanisch winnen van wadpieren binnen het concessiegebied "Balgzand/Breehorn en Middelplaat" voor VOF Zeepierenhandel H. Rotgans gevestigd te Hippolytushoef (gemeente Wieringen).

Gedeputeerde Staten Provincie Noord-Holland (2010c) Wnb Vergunning artikel 2.7, tweede lid voor de mechanische wadpierenvisserij, met het pierenwinschip 'MS Arenicola', binnen het concessiegebied Vlakte van Kerken en Krassekeet, voor de kust van Texel, gelegen in Natura 2000-gebied 'Waddenzee' voor Arenicola B.V. gevestigd in De Cocksdorp te Texel. Brief van Regionale Uitvoeringsdienst NoordHolland Noord, namens Gedeputeerde Staten Provincie Noord-Holland, gedateerd 20 december 2018.

Jongbloed, R.H. \& J.E. Tamis (2011) Nadere effectenanalyse Natura 2000-gebieden Waddenzee en Noordzeekustzone. Bijlagerapport Nb-vergunde visserij. IMARES rapport C172/11. Bijlage bij ARCADIS rapport 075248083, IMARES rapport C172/11.

Jongbloed, R.H., J.E. Tamis \& B.J.H. Koolstra (2011) Nadere effectenanalyse Natura 2000-gebieden Waddenzee en Noordzeekustzone. Deelrapport Cumulatie. IMARES rapport C174/11, ARCADIS rapport 075486183: $\mathrm{H}$.

Koffijberg, K. (2016) Populatieverloop van bontbekplevier, strandplevier en dwergstern nader onder de loep genomen. Voordracht, Themadag strandbroeders Castricum 17.11.2016.

https://assets.vogelbescherming.nl/docs/a827feb3-ae5d-4e00-97c3-2d028629ae62.pdf

Leopold, M.F. (2002) Eiders Somateria mollissima scavenging behind a lugworm boat. Journal of Sea Research 47: 75-82.

Ministerie van Infrastructuur en Milieu \& Rijkswaterstaat (2016) Natura 2000-beheerplan Waddenzee. Periode 2016-2022. Juli 2016.

Ministerie van LNV (2009a) Aanwijzingsbesluit Natura 2000-gebied Waddenzee. DRZO/2008-00.

Ministerie van LNV (2009b) Aanwijzingsbesluit Natura 2000 gebied Duinen en Lage Land Texel, Ministerie van LNV, Den Haag.

Natuurmonumenten (2015) Een rijk wad bij Texel. Natuurvisie De Schorren en de Vlakte van Kerken. 2015-2033. Datum: 30 november 2015. Natuurmonumenten Regio Noord-Holland en Utrecht. Zuidereinde 49, $1243 \mathrm{KL}$ 's-Graveland.

Natuur \& Ruimte (2018) Aanvullende gegevens aanvraag vergunning Wnb Arenicola B.V.

Zaaknummer: RUD.255242. Verzonden op 3 september 2018 naar Regionale Uitvoeringsdienst NoordHolland Noord. Opgesteld door portegijs@natuurenruimte.nl. www.natuurenruimte.com. IBAN: NL08 ASNB 0708129536.

Natuurmonumenten (2015) Een rijk wad bij Texel. Natuurvisie De Schorren en de Vlakte van Kerken. 2015-2033. Datum: 30 november 2015. Natuurmonumenten Regio Noord-Holland en Utrecht. Zuidereinde 49, $1243 \mathrm{KL}$ 's-Graveland.

Natuurmonumenten (2018) Telgegevens van broedvogels op De Schorren en De Volharding (Texel). Ontvangen van Nelleke Cornips, Medewerker Natuurdatabank, Natuurmonumenten op 25 oktober 2018.

Spaans, B., Leopold, M. \& Plomp, M. (2018) Bepaling van het aantal nesten en het uitvliegsucces van grote sterns op Texel met behulp van een drone. Limosa 91: 28-35.

Tulp, I. (1998) Reproductie van strandplevieren Charadrius alexandrinus en bontbekplevieren Charadrius hiaticula op Terschelling, Griend en Vlieland in 1997. Limosa 71: 109-120. 


\section{Verantwoording}

Rapport C125/19

Projectnummer: 4315100102

Dit rapport is met grote zorgvuldigheid tot stand gekomen. De wetenschappelijke kwaliteit is intern getoetst door een collega-onderzoeker en het verantwoordelijk lid van het managementteam van Wageningen Marine Research

Akkoord:

Dr. Oscar Bos

Marien ecoloog

Handtekening:

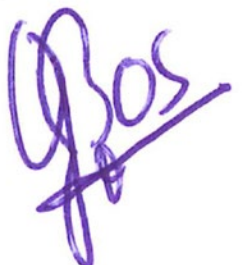

Datum:

9-12-2019

Akkoord: Drs. Jakob Asjes

Manager Integratie

Handtekening:

Datum:

9-12-2019 


\section{Bijlage 1 Lijst met werkwijze Arenicola B.V.}

\begin{tabular}{|c|c|}
\hline ARENICOLA B.V. - TEXEL & Huidige situatie (onveranderd sinds 2009\#) \\
\hline \multicolumn{2}{|l|}{ TECHNIEK PIERENWINNEN } \\
\hline Voortbeweging pierenboot & $\begin{array}{l}\text { Voortbeweging tijdens vissen m.b.v. ankerlier, } \\
\text { hydraulisch systeem. Ankerlijn van } 500 \text { m lengte en } \\
14 \mathrm{~mm} \text { diameter. Treksnelheid lier is digitaal } \\
\text { instelbaar. }\end{array}$ \\
\hline Diepte uitsnijden sediment & $\begin{array}{l}\text { Tussen } 25 \text { en } 35 \mathrm{~cm} \text {; digitale hoekmeting graver } \\
\text { waardoor diepte nauwkeurig instelbaar is. Bij de } \\
\text { vergunningaanvraag voor } 2019 \text { en verder, is } \\
\text { aangegeven dat de maximale diepte van de graver } \\
\text { verminderd is naar } 35 \mathrm{~cm} \text {. Bij voorschrift } 14 \text { van de } \\
\text { vorige vergunning is de maximale diepte nog } 40 \mathrm{~cm} \text {. } \\
\text { Dat wil niet zeggen dat er steeds op die diepte is } \\
\text { gevist. De diepte hangt af van de verblijfsdiepte van } \\
\text { de wadpieren en zal dus meestal ondieper zijn dan } \\
\text { het voorschrift } 14 .\end{array}$ \\
\hline Bodem losgewoeld met spoelsysteem & $\begin{array}{l}\text { Vanaf 1986, m.s. Arenicola, vijzelpomp voor } \\
\text { spoelwater. Kenmerken: lagere druk, veel water, } \\
\text { weinig vermogen (cf de Vlas 1999). }\end{array}$ \\
\hline Breedte snijbak & $\begin{array}{l}1,20 \mathrm{~m} \text {. Vanwege de wijziging in spoelsysteem is de } \\
\text { graver verbreed om de lagere snelheid te } \\
\text { compenseren }\end{array}$ \\
\hline Zijschermen & Zijschermen en lamellen \\
\hline Motorvermogen & Onveranderd vanaf voor 1990 \\
\hline Zuinigheid motor & Zelfde motoren \\
\hline Slaapaccomodatie & Afwezig \\
\hline Continue registratie kwaliteit & $\begin{array}{l}\text { Tijdens vissen is er een continue registratie van de } \\
\text { kwaliteit en daardoor bewaking van discards. } \\
\text { Systeem waardoor pieren gesorteerd worden op } \\
\text { kwaliteit. }\end{array}$ \\
\hline Digitale hoekmeting van graver & $\begin{array}{l}\text { Door digitale hoekmeting van graver is diepte- } \\
\text { instelling en de hoek waarmee de graver door de } \\
\text { bodem gaat uiterst nauwkeurig instelbaar. Er wordt } \\
\text { voortdurend rekening gehouden met het sediment } \\
\text { en de daarin levende dieren. Diepte van bodemleven } \\
\text { varieert met de seizoenen. }\end{array}$ \\
\hline Instelbaarheid treksnelheid lier & $\begin{array}{l}\text { De treksnelheid van de lier is digitaal instelbaar, } \\
\text { elektrisch hydraulisch. }\end{array}$ \\
\hline Satelliet/gps-kompas & $\begin{array}{l}\text { GPS op basis van RTK met een nauwkeurigheid van } \\
0,5 \mathrm{~cm} \text {. }\end{array}$ \\
\hline
\end{tabular}




\begin{tabular}{|l|l|}
\hline VERSTORING SEDIMENT EN BODEMDIEREN & \\
\hline Sediment en kleine bodemdieren & $\begin{array}{l}\text { Sediment en kleine bodemdieren worden volledig } \\
\text { onder water er al uit gezeefd. }\end{array}$ \\
\hline $\begin{array}{l}\text { Nauwkeurigheid terugstorten van sediment en kleine } \\
\text { bodemdieren in geul }\end{array}$ & $\begin{array}{l}\text { Teruggestort sediment komt voornamelijk in geul } \\
\text { terecht door de lagere opvoerhoogte en de } \\
\text { afscherming met zijschermen en lamellen. }\end{array}$ \\
\hline Overige, grotere, bodemdieren & Komen via lopende band weer in spoor graver. \\
\hline Overtijen van M.S. Arenicola & In de vaargeul. \\
\hline VISSERIJ & $\begin{array}{l}\text { Rondje lopen, regelmatig gps-posities in computer } \\
\text { plaatsen. Als voorheen wisselen van visgebied. }\end{array}$ \\
\hline Verspreiding visserij over het wad & $\begin{array}{l}\text { Houdbaarheid 2 weken (Hildebrandt 2008). Door de } \\
\text { kwaliteitsverbetering van pieren en verbeteringen in } \\
\text { transportmogelijkheden kan Arenicola zonder } \\
\text { antibiotica over grote afstanden pieren leveren. }\end{array}$ \\
\hline Resultaat kwaliteitsbewaking bij Arenicola marina \\
\hline Kwaliteitsbewaking overige bodemdieren & $\begin{array}{l}\text { Kwaliteitsbewaking vergroot, verminderde schade } \\
\text { aan bodemdieren. }\end{array}$ \\
\hline
\end{tabular}

\# behalve voor diepte uitsnijden sediment 


\section{Bijlage 2 Broedvogels van De Schorren}

Figuren van de ontwikkeling van het aantal broedvogelparen voorkomend in de periode $1978 \mathrm{t} / \mathrm{m}$ 1981 en 1992 t/m 2017 in het beheergebied op kwelder De Schorren. Hieronder zijn 13 broedvogelsoorten geselecteerd. Dit zijn acht broedvogelsoorten met een instandhoudingsdoelstelling voor de Waddenzee (lepelaar, eider, kluut, bontbekplevier, kleine mantelmeeuw, grote stern, visdief, noordse stern), aangevuld met vijf broedvogelsoorten die eveneens interessant zijn (scholekster, tureluur, kokmeeuw, stormmeeuw zilvermeeuw, grote mantelmeeuw) omdat ze ook op de Vlakte van Kerken kunnen foerageren op bodemdieren.

Elf broedvogelsoorten van de Schorren hebben een instandhoudingsdoelstelling voor de Waddenzee en deze staan in de tabel in Bijlage 2. Zeven van die 11 broedvogelsoorten hebben ook een instandhoudingsdoelstelling voor Duinen en Lage Land Texel. 


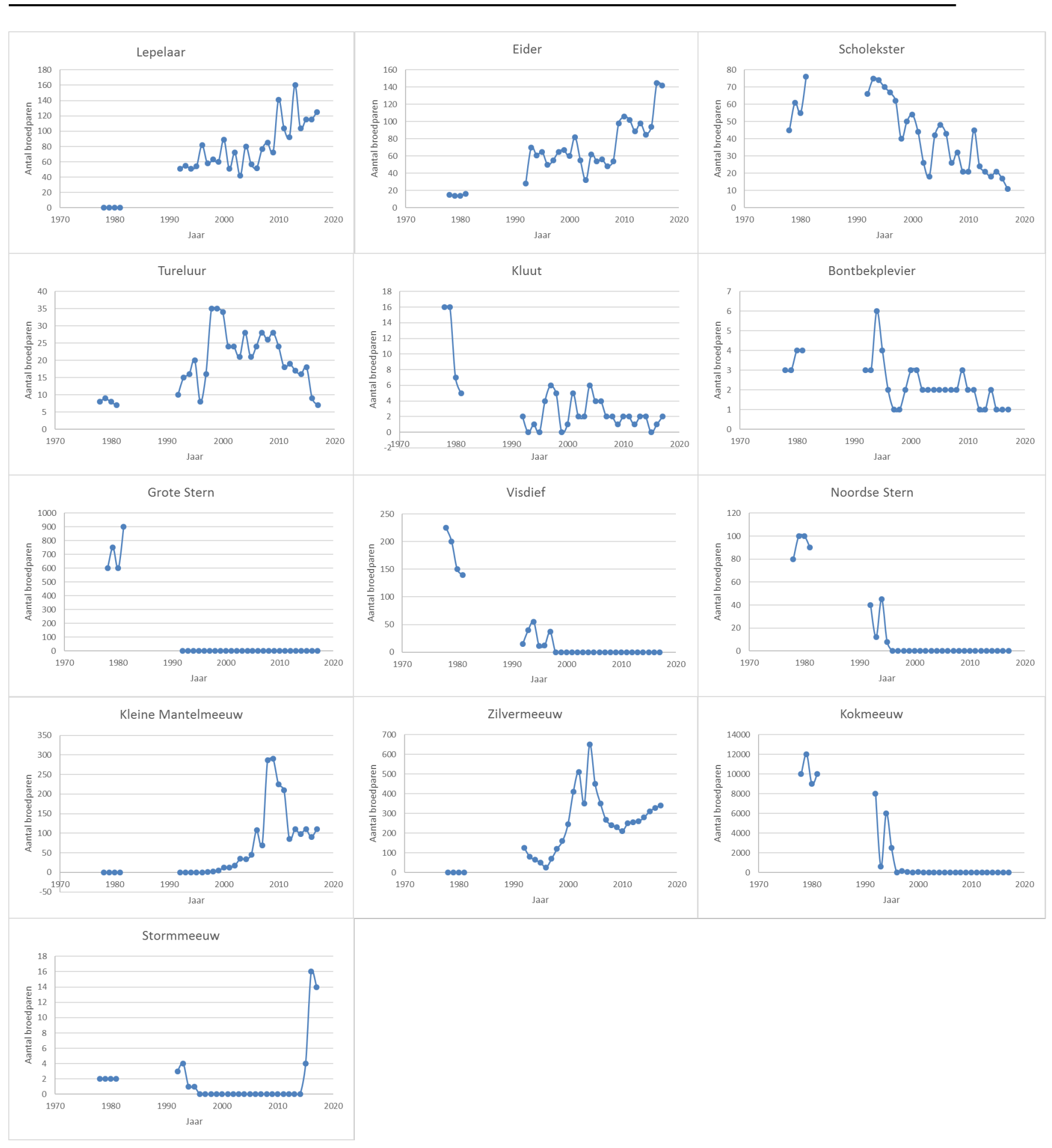


Broedvogelparen voorkomend in de periode 1992 tot en met 2017 in het beheergebied op kwelder De Schorren met hun trend in De Schorren en in Nederland en hun bedreigde status volgens de Rode Lijst (2017). Alleen de broedvogelsoorten met een instandhoudingsdoelstelling voor Natura 2000-gebied Lage Land Texel en Natura 2000-gebied Waddenzee worden hier getoond. Bron: Natuurmonumenten (2018).

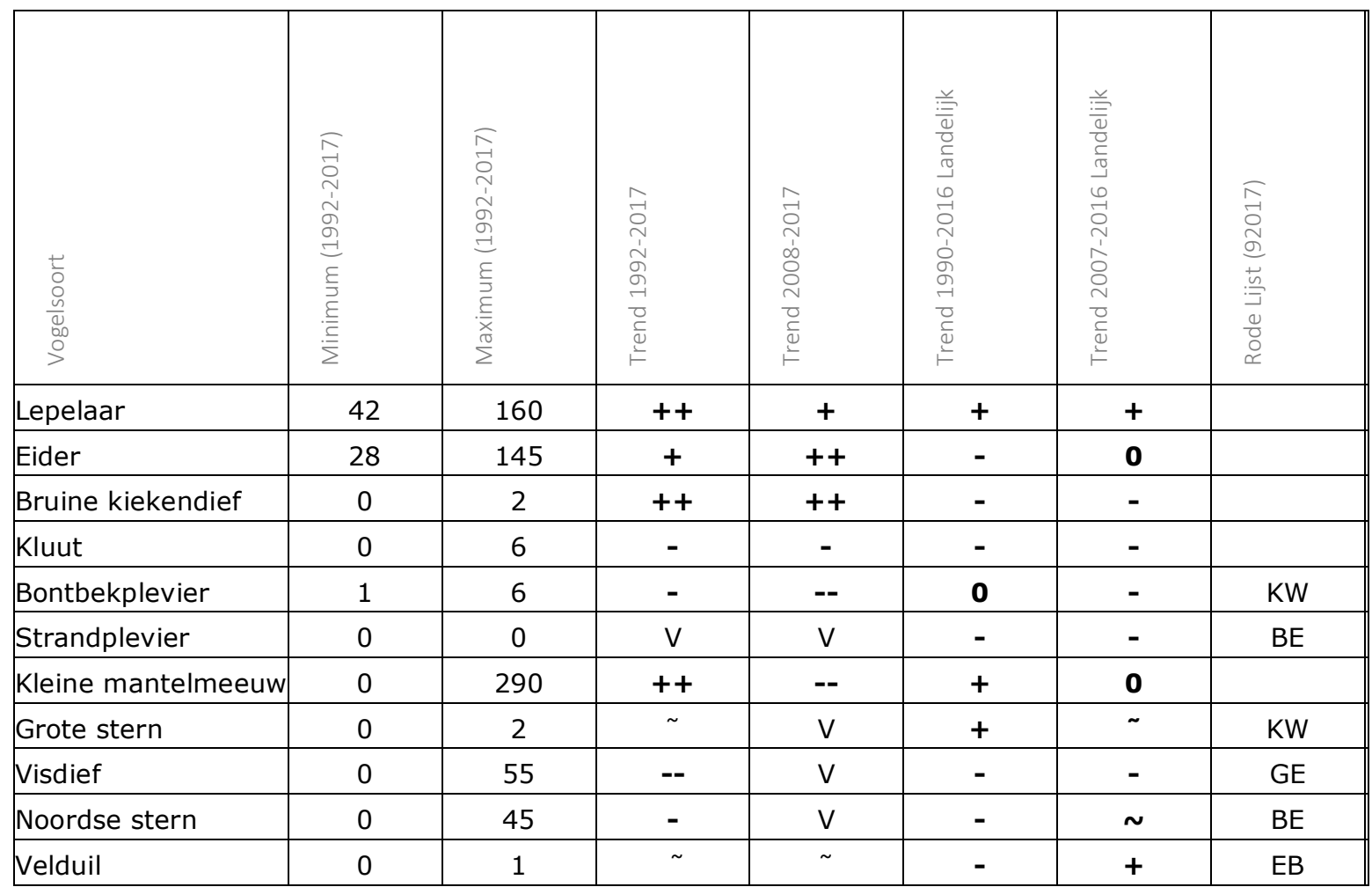

Verklaring trend symbolen: ++ betekent sterk stijgend ( $>5 \%$ per jaar), + betekent stijgend $(<5 \%$ per jaar), 0 betekent gelijk, - betekent dalend ( $<5 \%$ per jaar), -- betekent sterk dalend ( $>5 \%$ per jaar), betekent geen trend aantoonbaar, $\mathrm{V}$ betekent niet meer voorkomend. Rode lijst status afkortingen: $\mathrm{GE}=$ gevoelig, $\mathrm{KW}=$ kwetsbaar, $\mathrm{BE}=$ bedreigd, $\mathrm{EB}=$ ernstig bedreigd.

Toelichting: Met de broedvogels lepelaar, eidereend, kleine mantelmeeuw en zilvermeeuw gaat het goed op De Schorren. De eidereend is bovendien in toenemend aantal binnendijks van De Schorren gaan broeden, in het nieuw aangelegde gebied Utopia (Eric Menkveld, Natuurmonumenten, pers. comm.). De toename van de aantallen broedende grote meeuwen op De Schorren heeft echter wel geleid tot het vertrek van de diverse soorten sterns. Alleen de grote stern heeft zich vlak bij De Schorren weten te handhaven, en is zelfs sterk in aantal toegenomen, doordat zich sinds 2014 jaarlijks 3000-7000 paren vestigden in Utopia (Spaans et al. 2018). Toe- of afnames van de andere soorten zijn niet of nauwelijks relevant omdat het om zeer kleine aantallen broedvogels gaat. 


\section{Bijlage 3 Broedvogels van De Volharding}

Figuren van de ontwikkeling van het aantal broedvogelparen voorkomend in de periode $2000 \mathrm{t} / \mathrm{m}$ 2017 op kwelder De Volharding. Hieronder zijn zes broedvogelsoorten geselecteerd omdat deze een instandhoudingsdoelstelling voor de Waddenzee hebben (eider, bontbekplevier, strandplevier, visdief, dwergstern), aangevuld met twee broedvogelsoorten die eveneens interessant zijn voor deze evaluatie (scholekster, tureluur).

De zes broedvogelsoorten van De Volharding met een instandhoudingsdoelstelling voor de Waddenzee en zijn ook opgenomen in de tabel in Bijlage 3. Drie van die zes broedvogelsoorten hebben ook een instandhoudingsdoelstelling voor Lage Land Texel. 


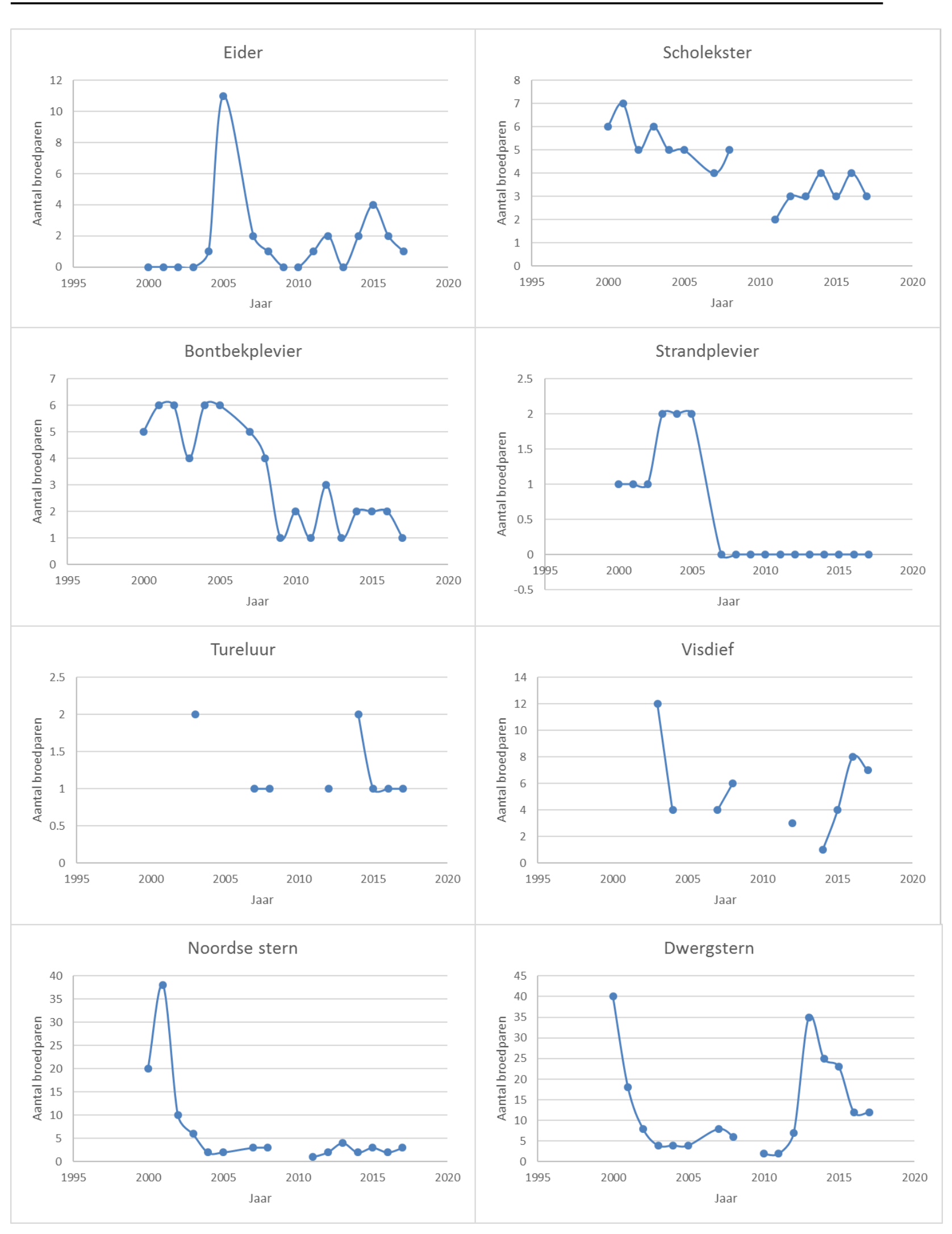


Broedvogelparen voorkomend in de periode 2000 tot en met 2017 in het beheergebied De Volharding met hun trend en bedreigde status volgens de Rode Lijst (2017). Alleen de broedvogelsoorten met een instandhoudingsdoelstelling voor Natura 2000-gebied Lage Land Texel en Natura 2000-gebied Waddenzee worden hier getoond. Bron: Natuurmonumenten (2015). Bron: Natuurmonumenten (2018).

\begin{tabular}{|c|c|c|c|c|c|c|c|}
\hline 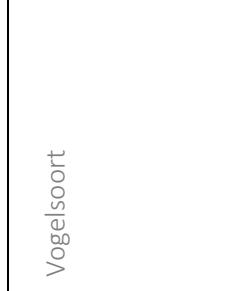 & 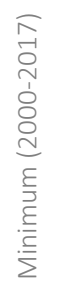 & 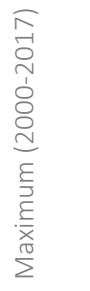 & 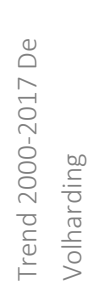 & 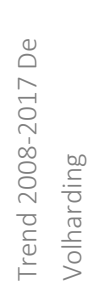 & 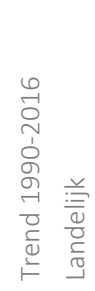 & 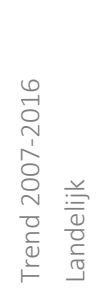 & 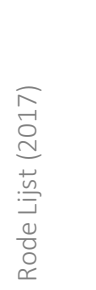 \\
\hline Eider & 0 & 11 & $\sim$ & $\sim$ & - & 0 & \\
\hline Bontbekplevier & 1 & 6 & -- & - & 0 & - & $\mathrm{KW}$ \\
\hline Strandplevier & 0 & 2 & -- & $\#$ & - & - & $\mathrm{BE}$ \\
\hline Visdief & 1 & 12 & $\sim$ & $\sim$ & - & - & GE \\
\hline Noordse stern & 1 & 38 & -- & $\sim$ & - & $\sim$ & $\mathrm{BE}$ \\
\hline Dwergstern & 2 & 40 & $\sim$ & ++ & + & 0 & $\mathrm{KW}$ \\
\hline
\end{tabular}

Verklaring trend symbolen: ++ betekent sterk stijgend ( $>5 \%$ per jaar), + betekent stijgend $(<5 \%$ per jaar), 0 betekent gelijk, - betekent dalend (<5\% per jaar), -- betekent sterk dalend ( $>5 \%$ per jaar), betekent geen trend aantoonbaar, $\mathrm{V}$ betekent niet meer voorkomend. Rode lijst status afkortingen: $\mathrm{GE}=$ gevoelig, $\mathrm{KW}=$ kwetsbaar, $\mathrm{BE}=$ bedreigd, $\mathrm{EB}=$ ernstig bedreigd.

Toelichting: De Volharding heeft sterk te leiden onder recreatie, met name van honden uitlaters (Marc Plomp, Vogelinformatiecentrum Texel, pers. comm.). Deze problemen spelen ook elders in Nederland, waardoor op veel plaatsen, inclusief op de Volharding, de aantallen strandbroeders afnemen (Tulp 1998; Koffijberg 2016). De negatieve trends voor scholekster, bontbekplevier, strandplevier, visdief en noordse stern op de Volharding passen in dit algemene beeld. Dwergsterns houden zich opvallend goed staande op de Volharding, een fenomeen dat ook landelijk optreedt (Koffijberg 2016). 
Wageningen Marine Research

T: $+31(0) 317480900$

E: marine-research@wur.nl

www.wur.nl/marine-research

Bezoekers adres:

- Ankerpark 27, 1781 AG Den Helder

- Korringaweg 7, 4401 NT Yerseke

- Haringkade 1, 1976 CP IJmuiden
Wageningen Marine Research levert met kennis, onafhankelijk wetenschappelijk onderzoek en advies een wezenlijke bijdrage aan een duurzamer, zorgvuldiger beheer, gebruik en bescherming van de natuurlijke rijkdommen in zee-, kust- en zoetwatergebieden.

Wageningen Marine Research is onderdeel van Wageningen University \& Research. Wageningen University \& Research is het samenwerkingsverband tussen Wageningen University en Stichting Wageningen Research en heeft als missie: 'To explore the potential of nature to improve the quality of life' 